ACCEPTED MANUSCRIPT

\title{
Assessing cardiac stiffness using ultrasound shear wave elastography
}

To cite this article before publication: Annette Caenen et al 2021 Phys. Med. Biol. in press https://doi.org/10.1088/1361-6560/ac404d

\section{Manuscript version: Accepted Manuscript}

Accepted Manuscript is "the version of the article accepted for publication including all changes made as a result of the peer review process, and which may also include the addition to the article by IOP Publishing of a header, an article ID, a cover sheet and/or an 'Accepted Manuscript' watermark, but excluding any other editing, typesetting or other changes made by IOP Publishing and/or its licensors"

This Accepted Manuscript is @ 2021 Institute of Physics and Engineering in Medicine.

During the embargo period (the 12 month period from the publication of the Version of Record of this article), the Accepted Manuscript is fully protected by copyright and cannot be reused or reposted elsewhere.

As the Version of Record of this article is going to be / has been published on a subscription basis, this Accepted Manuscript is available for reuse under a CC BY-NC-ND 3.0 licence after the 12 month embargo period.

After the embargo period, everyone is permitted to use copy and redistribute this article for non-commercial purposes only, provided that they adhere to all the terms of the licence https://creativecommons.org/licences/by-nc-nd/3.0

Although reasonable endeavours have been taken to obtain all necessary permissions from third parties to include their copyrighted content within this article, their full citation and copyright line may not be present in this Accepted Manuscript version. Before using any content from this article, please refer to the Version of Record on IOPscience once published for full citation and copyright details, as permissions will likely be required. All third party content is fully copyright protected, unless specifically stated otherwise in the figure caption in the Version of Record.

View the article online for updates and enhancements. 


\section{Assessing cardiac stiffness using ultrasound shear wave elastography}

Annette Caenena,b,c, Mathieu Pernot ${ }^{\mathrm{d}}$, Kathryn R. Nightingale ${ }^{\mathrm{e}}$, Jens-Uwe Voigtt,f, Hendrik J. Vos ${ }^{\mathrm{c}}$, Patrick Segers $^{\text {a*}}$, Jan D'hooge ${ }^{\text {b* }}$

alnstitute for Biomedical Engineering and Technology, Ghent University, Ghent, Belgium. ${ }^{b}$ Department of Cardiovascular Sciences, University of Leuven, KU Leuven, Leuven, Belgium. ${ }^{c}$ Department of Cardiology, Erasmus MC University Medical Center, Rotterdam, the Netherlands. ${ }^{d}$ Physics for Medicine, INSERM, CNRS, ESPCI, PSL University, Paris, France. eDepartment of Biomedical Engineering, Duke University, Durham (NC), United States. ${ }^{f}$ Department of Cardiovascular Diseases, University Hospital Leuven, KU Leuven, Leuven, Belgium. *Joint last author.

\section{Address for correspondence:}

Annette Caenen, Institute for Biomedical Engineering and Technology, Ghent University, Campus Heymans - Blok B, Corneel Heymanslaan 10, 9000 Gent, Belgium. Phone: +32 93320258. Email: annette.caenen@ugent.be 


\section{Abstract}

Shear wave elastography offers a new dimension to echocardiography: it measures myocardial stiffness. Therefore, it could provide additional insights into the pathophysiology of cardiac diseases affecting myocardial stiffness and potentially improve diagnosis or guide patient treatment. The technique detects fast mechanical waves on the heart wall with high frame rate echography, and converts their propagation speed into a stiffness value. A proper interpretation of shear wave data is required as the shear wave interacts with the intrinsic, yet dynamically changing geometrical and material characteristics of the heart under pressure. This dramatically alters the wave physics of the propagating wave, demanding adapted processing methods compared to other shear wave elastography applications as breast tumor and liver stiffness staging. Furthermore, several advanced analysis methods have been proposed to extract supplementary material features such as viscosity and anisotropy, potentially offering additional diagnostic value. This review explains the general mechanical concepts underlying cardiac shear wave elastography and provides an overview of the preclinical and clinical studies within the field. We also identify the mechanical and technical challenges ahead to make shear wave elastography a valuable tool for clinical practice. 
Two-dimensional

Three-dimensional

Atrial kick

Apical three-chamber view

Apical four-chamber view

Acoustic radiation force

Aortic valve closure

Echocardiogram

End-diastolic

End-diastolic pressure

End-systolic pressure

Fractional anisotropy

Fast Fourier transform

Hypertrophic cardiomyopathy

Hypertension

Heart transplantation

Healthy volunteer

Interventricular septum

Left anterior descending coronary artery

Left circumflex coronary artery

Left ventricle

Left ventricular free wall

Myocardial infarction

Mechanical stimulation

Mitral valve closure

Parasternal long axis view

Parasternal short axis view

Shear wave elastography

Time-of-flight

Ultrasound

Valve closure 


\section{Introduction}

Echocardiographic evaluation of cardiac function is indispensable for the diagnosis and treatment of any cardiovascular disease. For many years, various indices based on measures of ventricular geometry and/or velocity measurements of blood flow and tissue have been proposed for the assessment of systolic or diastolic function, but none of these allow for a complete description of cardiac function. Indeed, cardiac distensibility and contractility - two important determinants of cardiac function - are tightly intertwined with active and passive myocardial stiffness, which is intrinsically linked with alterations at the level of the cardiomyocytes, crossbridge actin-myosin interactions and the composition of the extracellular matrix. Non-invasive ultrasound based evaluation of tissue stiffness started in the late 1980s to early 1990s, when a field based on the old technique of palpation was founded: ultrasound (US) elastography (Ophir et al., 1991; Gao et al., 1996). Later, around 2010, the advent of high-frame rate imaging meant a dogma shift for medical US: the entire field of view was insonified for every transmit in order to enable image reconstruction on receive at high frame rates (> 500 frames/s) in contrast to the conventional lineby-line scanning. This high frame rate imaging modality enabled new methodologies in elastography (Villemain et al., 2020). In this review, we focus on one specific class of high frame rate techniques within the field of ultrasound elastography, referred to as shear wave elastography (SWE). Other imaging fields such as magnetic resonance imaging have developed similar technologies and we refer the reader interested in magnetic resonance elastography to literature on the topic, e.g. (Elgeti and Sack, 2014).

SWE - as the name suggests - uses the propagation characteristics of shear waves to estimate the stiffness of the tissue in which they propagate. Shear waves are naturally induced in the heart upon closure of atrio-ventricular or ventriculo-arterial valves, but may also be mechanically induced using an external source. SWE has been clinically successful in various non-cardiac domains, such as staging liver fibrosis (Ferraioli et al., 2015) and characterizing malignant breast lesions (Barr et al., 2015). The potential of the method to directly assess passive - and active myocardial stiffness exists, but the method is faced with challenges relating to its fundamental working principles when applied to the heart. Indeed, the geometrical and mechanical properties of the heart - thin-walled, anisotropic, layered, actively contracting (in short: mechanical factors) - are more complex than that of large nonlinear viscoelastic organs such as the breast and the liver, evoking an altered wave physics that obeys different physical principles. With it, also the interpretation of the observed shear waves and the deduction of tissue properties becomes more complex.

This paper reviews the basic/concepts of cardiac ultrasound SWE and gives an overview of the (pre)clinical studies that have investigated the effect of one or multiple mechanical factors and pathology on shear wave propagation. This way, the reader will be able to better understand shear wave measurements in the cardiac setting and interpret findings from a biophysical point of view. Shear wave speed values reported for healthy volunteers and various preclinical and patient studies (myocardial infarction, hypertrophic cardiomyopathy, amyloidosis, heart transplantation, hypertension) are summarized. The paper concludes with recommendations on uniform reporting and identification of the main mechanical (and technical) challenges ahead. 


\section{Definitions}

The stiffness of a solid material, such as cardiac tissue, relates to the relation between its loading and subsequent deformation, typically described by the normalized physical quantities stress and strain respectively. In continuum mechanics, one typically expresses material stiffness (or modulus) as the mathematical relationship between stress and strain. In clinical practice (where it is often impossible to assess stress and strain), one often uses structural stiffness, which depends on material stiffness but also on its geometry and boundary conditions (Guimarães et al., 2020; Fung, 1993). Biological tissue is often approximated as a linear elastic isotropic material in the field of elasticity imaging, in which the stress $\sigma$ linearly depends on the strain $\varepsilon$ regardless of the material's orientation (i.e. isotropy), as visualized in Figure 1a. The slope of the curve represents the elasticity or Young's modulus $E$, expressing the material's resistance to uniaxial tension/compression. The relative material deformation in the direction perpendicular to the loading direction is then given by Poisson's ratio $v$. Other/important moduli that describe the material's response to different kinds of loading are the shear modulus $\mu$ (material's resistance to simple shear loading) and the bulk modulus $K$ (material's resistance to volumetric changes).

The linear elastic isotropic material model is a good first order approximation for some tissues (e.g. liver), but in general material properties of tissue are essentially dependent on material orientation (anisotropy), time (viscoelasticity) and stretch state (material non-linearity or hyperelasticity), as shown in Figure 1. This figure also demonstrates the meaning of instantaneous or operational stiffness (local slope of the $(\varepsilon, \sigma)$-relationship): a higher instantaneous stiffness - indicated by $E_{\text {high }}$ in Figure $1 \mathrm{~b}$ - might be related to higher strains (hyperelastic effect), higher strain rate (viscoelastic effect) or fiber orientation (anisotropic effect). In addition, the apparent stiffness of a muscle can be modified by internal stress induced by active contraction.

a.

Linear elasticity

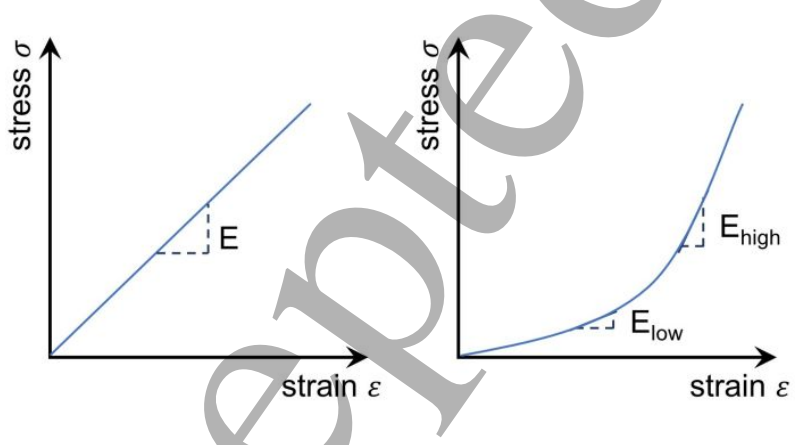

b.
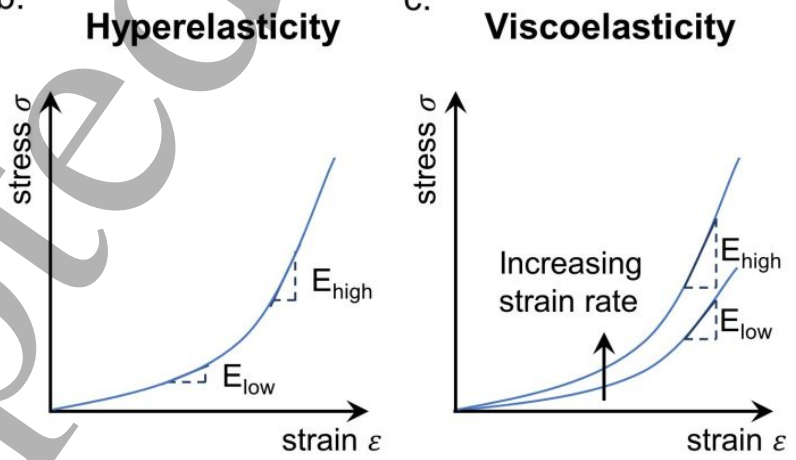

d.

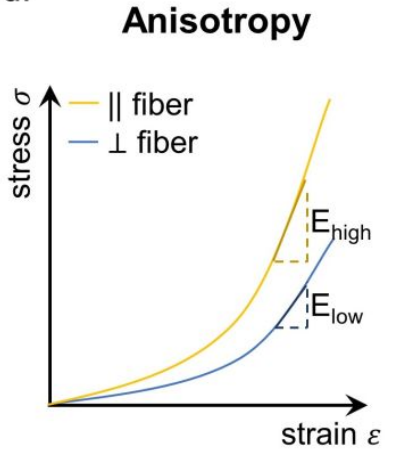

Figure 1 -Mechanical engineering definitions: conceptual representation of linear elasticity (a), hyperelasticity (b), viscoelasticity (c) and anisotropy (d) in terms of stress-strain curves.

\section{Theoretical background - relating stiffness to wave propagation}

Theoretically, only two wave modes can exist in an isotropic bulk material: a shear wave, and a compressional wave. These wave modes are distinct in the local particle motion (or deformation) 
relative to the direction of propagation (see Figure 2a): a shear or transversal wave has particle motion perpendicular to the propagation direction, whereas a compressional (or longitudinal) wave particle motion parallel to the propagation direction. These compressional waves are the acoustic waves that are used for standard echography. The propagation speeds of these two wave types are linked to different tissue material properties of the medium in which they propagate. When approximating tissue as an infinite isotropic linear elastic medium (without viscosity), the following relations hold true (Cobbold, 2002):

$$
\begin{gathered}
c_{T}=\sqrt{\frac{\mu}{\rho}} \\
c_{L}=\sqrt{\frac{K+\frac{4}{3} \mu}{\rho}}
\end{gathered}
$$

with shear wave propagation speed $c_{T}$, shear modulus $\mu$, mass density $\rho$, longitudinal wave propagation speed $c_{L}$, and bulk modulus $K$. A mass density of $1000 \mathrm{~kg} / \mathrm{m}^{3}$ is commonly assumed.

It is important to stress that pure shear and compression waves only exist in an infinite, homogenous, isotropic medium, for which Eqs. 1 and 2 describe the wave propagation velocities. These equations are only valid for plane waves, as a finite source of excitation also results in a shear wave with longitudinal polarization and a longitudinal wave with shear polarization (Catheline and Benech, 2015). This shear wave with longitudinal polarization is the base of 1D transient elastography (Catheline et al., 1999; Sandrin et al., 1999). Furthermore, a confined geometry or inhomogeneous and direction-dependent material properties - all of which are true for the myocardium - might evoke other wave modes than a shear wave (e.g. vertical/horizontal shear waves in transverse isotropic media (Wang et al., 2013; Rouze et al., 2013), Lamb waves in plate-like geometries (Caenen et al., 2017; Keijzer et al., 2020b)). Wave motion can then have a longitudinal component next to a transversal component. This should be considered when interpreting the mechanical waves detected with echocardiography and will be discussed in detail further in this review (see Shear wave imaging and reconstruction of shear wave speed maps).

In principle, both shear and bulk modulus are expected to correlate to tissue composition, and hence to disease state. However, when comparing the two wave modes in terms of clinical applicability for elasticity imaging, shear waves have been preferred for tissue characterization because: (i) their wave propagation speed has a larger range compared to longitudinal waves (speed range of $0.5-20 \mathrm{~m} / \mathrm{s}$ vs. $1350-1700 \mathrm{~m} / \mathrm{s}$ in soft tissues (Cobbold, 2002)) making it easier to distinguish differences in speed; (ii) their wave propagation speed is elevated by pathological changes (up to two orders of magnitude (Greenleaf et al., 2003)) and (iii) tissue Doppler echography with a frame rate in the order of $\mathrm{kHz}$ can be used to track shear waves .

Shear wave speed estimation in a thin-walled viscoelastic medium such as the cardiac wall is not straightforward as a shear wave of a finite temporal length intrinsically contains a range of frequencies - as an ultrasound pulse - and these frequencies can travel at different speeds, a phenomenon which is called speed dispersion. In general, there are two manners to characterize 
a.

Longitudinal wave propagation

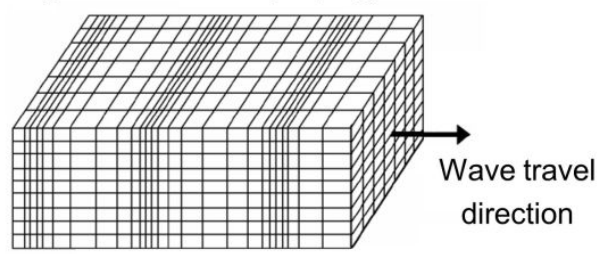

Shear wave propagation

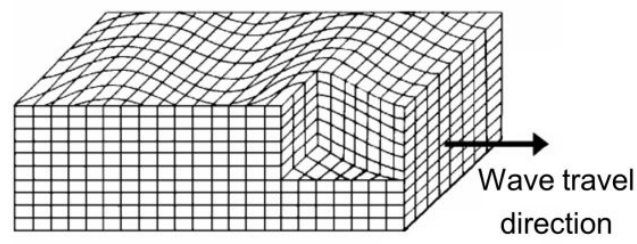

b. Wave propagation without dispersion

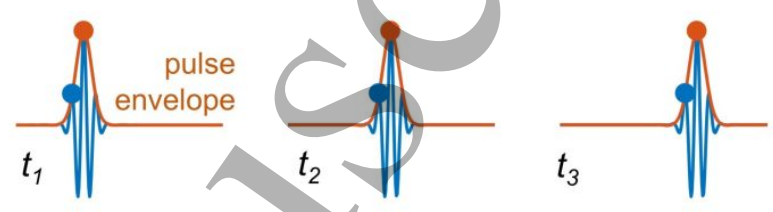

Wave propagation with dispersion

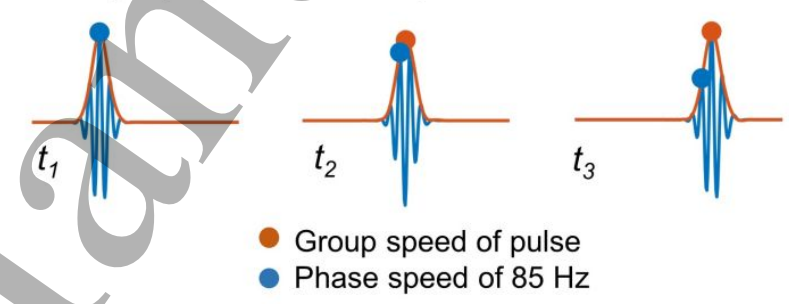

Figure 2 - Basic wave physics principles. (a) Direction of the tissue motion and wave propagation for longitudinal and shear wave propagation (adapted from (Cobbold, 2002)). (b) Concept of group and phase speed. Individual waves with a specific frequency propagate at the phase speed (blue dot); whereas the pulse envelope propagates at the group speed (orange dot).

\section{Cardiac ultrasound shear wave elastography}

\section{Shear wave excitation sources}

SWE can be realized in different manners, where the source of excitation of the shear waves is an important distinguishing criterion for cardiac SWE (see also Figure 3 and Table 1):

- Acoustic radiation force (ARF): by applying a high-intensity focused US beam for a relatively long period of time but still in an impulsive manner $(<1 \mathrm{~ms})$, a localized body force is generated of a sufficiently large magnitude to evoke particle displacements in the order of a few micrometers in the direction of the US beam (Song et al., 2014; Sarvazyan et al., 1998; Nightingale et al., 2001). In other words, the US beam literally pushes the tissue away from the transducer, while the transducer is at a distance. For cardiac SWE, the geometrical shape of the ARF is typically ellipsoidal around the US beam axis with a length encompassing the thickness of the cardiac wall (using a strongly focused US beam or a low emission frequency). The wall region of interest should be oriented parallel with the transducer surface such that the "push" excites mainly transverse motion, which is a condition best met in the parasternal long or short axis (PLAX/PSAX) view of the 
interventricular septal wall for transthoracic closed-chest settings, but more nonconventional views are feasible in an open-chest setting.

- Intrinsic motion (natural waves): mechanical waves are also caused by fast transient events in the heart such as valve closure. Previous research mainly focused on the mechanical wave propagation in the left ventricle after mitral and aortic valve closure (MVC, AVC) (Vos et al., 2017; Santos et al., 2018; Kanai, 2005) but also after atrial kick (AK) (Pislaru et al., 2014a). As the spatial and temporal properties of the excitation source are unknown, the understanding of the measured phenomena remains poor. A recent 3D study on natural waves (Papadacci et al., 2020) has shown that there might be two sources of wave excitation after MVC, but these results are still very preliminary $(n=3)$. Natural waves after valve closure contain both transversal and longitudinal components of tissue motion, explaining why analyses based on both parasternal and apical views have been reported in literature (Keijzer et al., 2020b; Brekke et al., 2014). Mechanical waves following AK did not reveal any wave-like pattern in the parasternal view, suggesting that AK's wave motion is predominantly longitudinal (Strachinaru et al., 2019b) and therefore this wave phenomenon is not further considered in this review.

- External mechanical actuator: some studies (Urban et al., 2013; Pislaru et al., 2014b; Tzschatzsch et al., 2012) reported the use of an actuator vibrating at a specific frequency to induce a monochromatic (i.e. single frequency) mechanical wave. This excitation method is typically used in magnetic resonance elastography (Mariappan et al., 2010; Elgeti et al., 2014), and has been used in ultrasound elastography as well to study the induced shear wave amplitude in healthy volunteers as a qualitative measure of stiffness (Tzschatzsch et al., 2012). However, to use SWE in a more quantitative way (as reported in Table 1), the monochromatic excitation is repeated at multiple frequencies to reconstruct the frequency behavior of the shear wave for the estimation of material parameters. The use of this method has only been reported in open-chest studies (Nenadic et al., 2018; Pislaru et al., 2014b). 

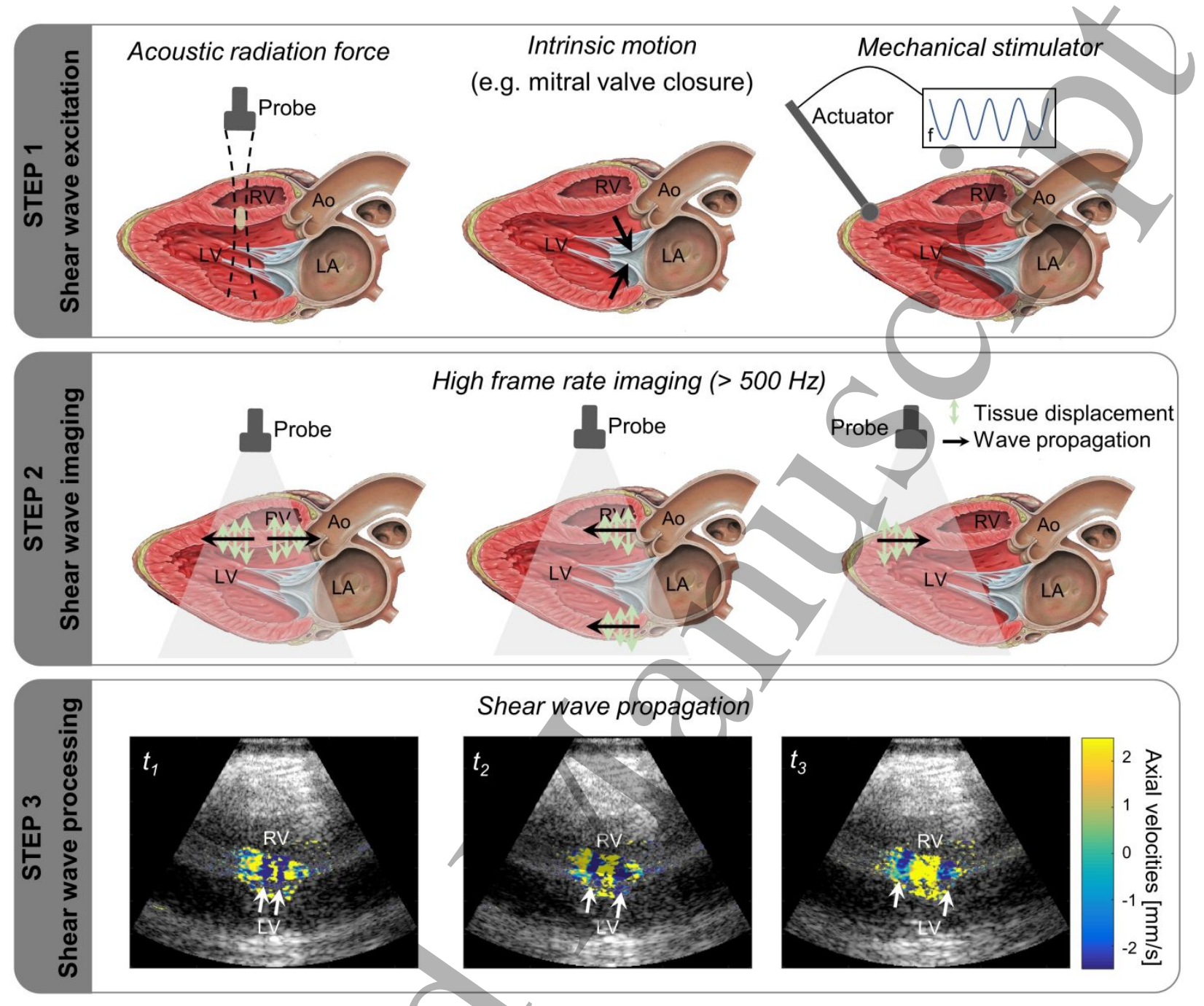

Figure 3 - Principle of ultrasound SWE in a cardiac setting (anatomical image adapted from (Olson and Pawlina, 2008)). Shear wave propagation shown as example in step 3 is measured in vivo in the interventricular septum of a closed-chest pig using an acoustic radiation force for shear wave excitation in an ongoing study (approved by the Ethical Committee for Animal Experiments of KULeuven P041/2019).

It should be noted that mechanical waves after valve closure occur at specific locations and moments in the cardiac cycle, whereas an ARF-induced shear wave is in theory fully controllable in time and space by the user, as much as the acoustic windows allow for. However, transthoracic excitation of shear waves in an acoustically safe manner remains challenging due to the limited aperture size (small acoustic windows) and small amplitude and quickly attenuating tissue motion in especially the stiff cardiac wall in systole. The use of intracardiac (Hollender et al., 2012) or trans-esophageal (Kwiecinski et al., 2015) transducers might offer a solution to this problem, but this comes with patient discomfort, increased health risks, and demanding technical requirements - small piezoelectric elements with enough power to generate a sufficiently large ARF. An advantage of intrinsic mechanical waves is their displacement magnitude which is one order of magnitude larger than that of ARF-induced waves (Table 1), improving the signal-to-noise ratio (SNR) of SWE. Additionally, transthoracic imaging of natural waves does not pose any problems regarding acoustic safety, permitting an easy implementation in clinical practice. 
Table 1 - Overview of different wave excitation sources in ultrasonic cardiac SWE with typical application settings and shear wave properties (IVS: interventricular septum; LVW: left ventricular wall; LVFW: left ventricular free wall; NR: not reported; PLAX: parasternal long-axis view; PSAX: parasternal short-axis view).

\begin{tabular}{|c|c|c|c|c|c|c|}
\hline & $\begin{array}{l}\text { Excitation } \\
\text { source }\end{array}$ & Timing & $\begin{array}{l}\text { Frequency } \\
\text { content }\end{array}$ & $\begin{array}{l}\text { Tracked } \\
\text { tissue } \\
\text { motion }\end{array}$ & $\begin{array}{l}\text { Cardiac wall } \\
\text { location }\end{array}$ & Reported metrics \\
\hline \multirow{2}{*}{ 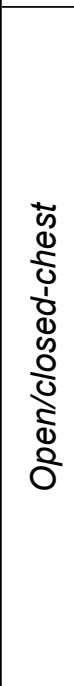 } & $\begin{array}{l}\text { Acoustic } \\
\text { radiation } \\
\text { force } \\
\text { (impulsive) }\end{array}$ & $\begin{array}{l}\text { Any } \\
\text { instant in } \\
\text { cardiac } \\
\text { cycle* }\end{array}$ & $\begin{array}{l}<500 \mathrm{~Hz} \\
\text { (Sarvazyan } \\
\text { et al., } \\
2013)\end{array}$ & $\begin{array}{l}\text { Transversal } \\
\sim 5 \mu \mathrm{m} \text { (Song } \\
\text { et al., 2014) }\end{array}$ & $\begin{array}{l}\text { IVS in } \\
\text { PLAX/PSAX } \\
\text { LVFW } \\
\text { (open-chest) }\end{array}$ & $\begin{array}{l}\text { Group speed (Keijzer ét al., } \\
\text { 2020a) } \\
\text { Elasticity (Villemain et al., 2018) } \\
\text { Group speed (Couade et al., } \\
\text { 2011; Bouchard et al., 2009) } \\
\text { Group speed, elasticity, } \\
\text { viscosity (Nenadic et al., 2018) }\end{array}$ \\
\hline & $\begin{array}{l}\text { Intrinsic } \\
\text { motion }\end{array}$ & AVC/MVC & $\begin{array}{l}<150 \mathrm{~Hz} \\
\text { (Kanai, } \\
2005 ; \text { Vos } \\
\text { et al., } \\
2017 ; \\
\text { Pernot and } \\
\text { Villemain, } \\
\text { 2019) }\end{array}$ & $\begin{array}{l}\text { Transversal } \\
\sim 100 \mu \mathrm{m} \\
\text { (Vos et al., } \\
2017 \text {; Santos } \\
\text { et al., 2018) } \\
\text { Longitudinal }\end{array}$ & $\begin{array}{l}\text { Mainly IVS in } \\
\text { PLAX } \\
\text { IVS in } \\
\text { AP3C/AP4C } \\
\text { (Brekke et } \\
\text { al., 2014; } \\
\text { Keijzer et al., } \\
\text { 2020b) } \\
\end{array}$ & $\begin{array}{l}\text { Group speed (Santos et al., } \\
\text { 2018; Salles et al., 2019; Keijzer } \\
\text { et al., 2019) } \\
\text { Group speed, phase speed (Vos } \\
\text { et al., 2017) } \\
\text { Phase speed, elasticity, } \\
\text { viscosity (Kanai, 2005) }\end{array}$ \\
\hline 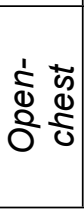 & \begin{tabular}{|l|} 
External \\
vibrator
\end{tabular} & $\begin{array}{l}\text { Any } \\
\text { instant in } \\
\text { cardiac } \\
\text { cycle }\end{array}$ & $\begin{array}{l}50-400 \mathrm{~Hz} \\
\text { in steps of } \\
50 \mathrm{~Hz} \\
\text { (Pislaru et } \\
\text { al., 2014b) }\end{array}$ & $\begin{array}{l}\text { Transversal } \\
10-100 \mu \mathrm{m} \\
\text { (Pislaru et al }\end{array}$ & LVFW & $\begin{array}{l}\text { Phase speed, elasticity, } \\
\text { viscosity (Pislaru et al., 2014b; } \\
\text { Urban et al., 2013) }\end{array}$ \\
\hline
\end{tabular}

${ }^{*}$ Very low success rate in systole.

Shear wave imaging and reconstruction of shear wave speed maps

High frame rate imaging (frame rate $>500 \mathrm{~Hz}$ ) is applied to visualize the propagating shear wave. The use of diverging wave imaging in a fundamental (Santos et al., 2018) or pulse-inversion harmonic (Song et al., 2013) manner has been reported for this purpose. Spatial resolution and contrast can be further improved by coherently compounding diverging waves emitted from multiple angles (Montaldo et al., 2009) or zones (Santos et al., 2018). After recording the shear wave motion, a tissue motion estimator is applied to the radio-frequency (RF) or demodulated in phase quadrature (IQ) data (e.g. a standard Doppler auto-correlator as the one described by Kasai et al. (Kasai et al., 1985)). The use of tissue displacement, velocity and acceleration have been reported to visualize shear wave motion in cardiac SWE (Deng et al., 2017; Nenadic et al., 2018; Santos et al., 2018).

For shear wave speed estimation, the first step is to select a wave propagation path along the cardiac wall which also includes the shear wave excitation source (white line in Figure 4a). The excitation source is always included in the imaging plane for ARF-induced waves as the same transducer is used to generate and detect shear waves, but attention should be paid to include the valves in the imaging plane when visualizing waves after intrinsic motion (Villemain et al., 2020). A curved (anatomical) M-mode displaying tissue motion data as a function of space and time is then obtained, as illustrated in Figure $4 \mathrm{~b}$. Various methods have been reported in literature 
to distinguish the high frequency wave motion from the low frequency gross cardiac motion in this M-mode: application of a high-pass filter on tissue motion data (Vos et al., 2017; Keijzer et al.) 2019) (example is shown in Figure 4b-c) or on the IQ data (Salles et al., 2019), subtraction of the average wall motion (Pernot et al., 2016) or representation of tissue motion in the form of accelerations (Santos et al., 2018). Shear wave speed estimation is then typically performed using a time-of-flight (TOF) estimator, which characterizes the shear wave's position as a function of time (see Figure 4c). The resulting speed can be classified as phase speed when using a single frequency source (external vibrator in Table 1), and as group speed when using a broadband excitation (ARF/intrinsic motion in Table 1) (Parker et al., 2018). Note that the phase speeds of all excited frequencies in the shear wave motion can be studied by repeating the measurement at a different frequency in case of an external vibrator or performing a Fourier analysis in the frequency domain in case of ARF/intrinsic motion (speed dispersion analysis (Deffieux et al., 2009)). Most studies report shear wave speed as an end result, whereas others convert speed $c_{T}$ into Young's modulus $E$ through equation (1) and the following equation:

$$
E=2(1+v) \mu \approx 3 \mu
$$

with Poisson's ratio $v$ (usually assumed 0.5 to describe tissue incompressibility (Fung, 1993)). Note that application of equation (3) implies that the myocardium is a priori considered an isotropic linear elastic material, and all observed wave phenomena are analyzed and interpreted within that paradigm. Unfortunately, this is an over-simplification, and it remains poorly understood how the conversion to true stiffness constants can be made accurately for the myocardium.

a.

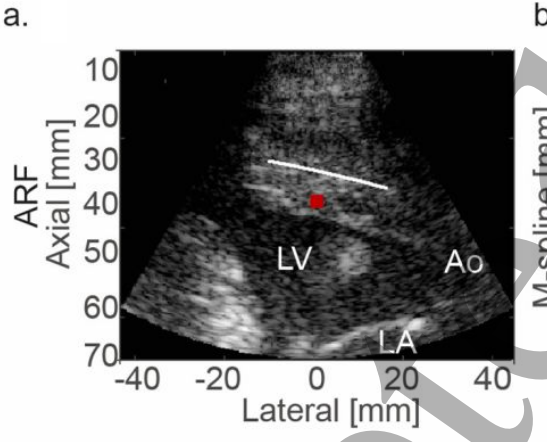

b.
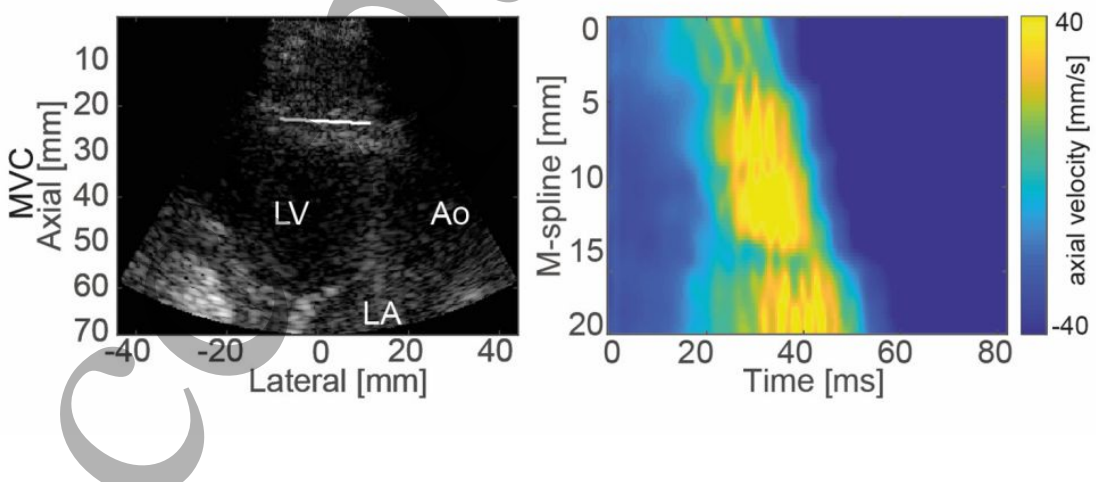

c.

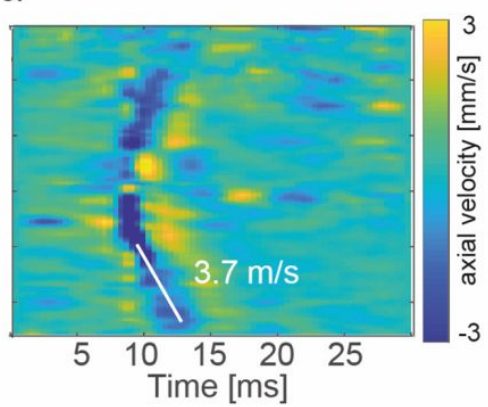

Figure 4-Reconstruction of shear wave speed. (a) B-mode in parasternal long-axis view for acoustic radiation force (ARF) induced shear waves in the upper panel (red rectangle indicates push focus) and shear waves induced by mitral valve closure (MVC) in lower panel. (b) Measured tissue motion. (c) Measured shear wave motion after 
application of band pass filter with cut-off frequencies at 75-750 Hz for ARF-induced wave and 15-100 Hz for MVCinduced wave. For ARF-based SWE, two shear waves are created in the center of the field of view (in the IVS); whereas for natural SWE one shear wave is propagating from base to apex. Adapted with permission from Keijzer and Caenen et al. (Keijzer et al., 2020a).

Recently, 3D high frame rate approaches have been reported in cardiac SWE through the use of ECG stitching (Salles et al., 2020) or coupling multiple US systems (Papadacci et al., 2020). Both approaches have been applied for imaging natural waves for which the wave propagation physics is less well defined than for ARF-induced waves. These 3D approaches allow to first apply a wave excitation source localization method to determine the wave propagation path for local wave speed estimation using a TOF algorithm.

\section{Mechanical factors affecting shear wave speed in the heart - what causes complexity?}

The interpretation of measured shear waves in the heart is complex due to multiple mechanical factors directly affecting shear wave speed values and interfering with effects of pathology. In this section, we review how geometry, viscosity, anisotropy, contraction/relaxation, hemodynamics, and pathology affect shear wave patterns and speed (Figure 5). We first macroscopically describe the effect of each factor on shear wave propagation and summarize its impact on reported wave speed variations in Table 2. Diastolic and systolic speeds are reported in separate columns, with the speed of the mechanical waves after MVC and AVC classified as diastolic and systolic speed, respectively (even though this classification is debatable as in some definitions the diastolic and systolic phases are ending at the moment of valve closure). 


\section{Geometry}

Figure 5 - Mechanical factors affecting wave speed esțimation in cardiac shear wave elastography.

Pure shear waves theoretically only exist in an infinite medium, a condition that is sufficiently met when the shear wavelength is significantly smaller than the smallest dimension of the medium in which it travels. In general, the studied wavelength in cardiac SWE depends on the selected excitation source (see Table 1), typically a few $\mathrm{mm}$ for ARF-induced waves and a few $\mathrm{cm}$ for natural waves, which is of the same order of magnitude or larger than the cardiac wall thickness (Kanai, 2005; Urban et al., 2013; Nenadic et al., 2018; Pislaru et al., 2014b). This means that the wave will reflect from the boundaries, confining the mechanical energy within the wall (Figure 6a) leading to guided waves. The wave front might be visually distorted during propagation (Figure $6 b)$, potentially resulting in a depth-dependent shear wave propagation speed as visualized in Figure $6 \mathrm{~b}$ for a left ventricular phantom. Also, the wave guide can result in dispersive effects, with the phase speed increasing as a function of frequency, as illustrated in Figure $6 \mathrm{~b}$ and tabulated in Table 2 (Rose, 2014). The nature of the shear wave is thus altered and consequently the propagation characteristics are not only dependent on stiffness - as one would conclude from equation (1) - but also on geometry, tissue surrounding and excitation characteristics. LV phantom experiments and simulations have shown that the TOF method can underestimate the true stiffness up to $35 \%$ for ARF-based SWE depending on wall thickness and echocardiographic view (Caenen et al., 2017). A recent study also investigated the effect of the thickness variations of the cardiac wall in simulations, showing a similar shear stiffness error for ARF-based SWE and an error of up to $65 \%$ for natural SWE (Sabbadini et al., 2021). The Lamb wave theory on waves 
in plates has been used to better understand the geometrical effect on cardiac shear wave propagation and to improve shear wave characterization methods, on which more information can be found in the appendix.

a.
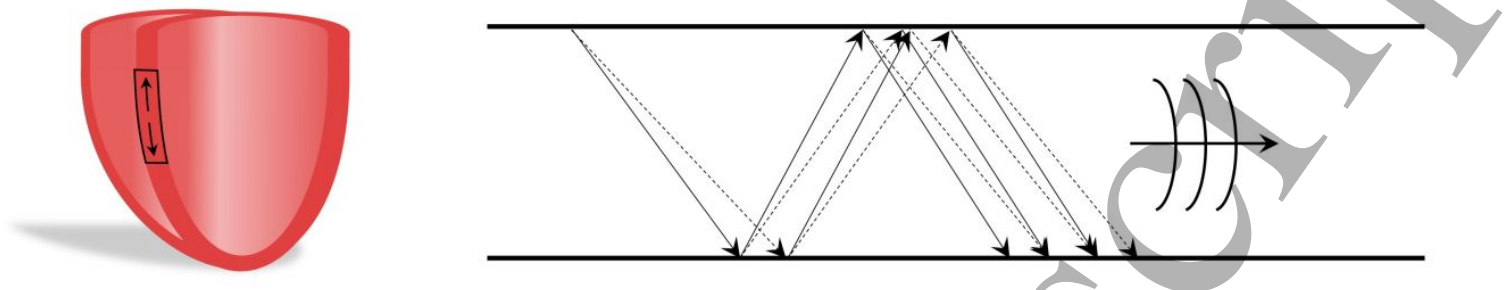

b. Wave propagation

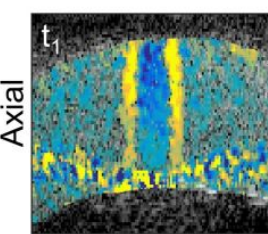

Lateral

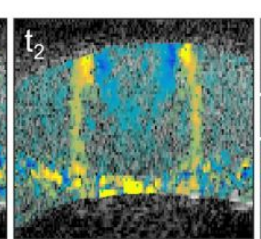

Lateral

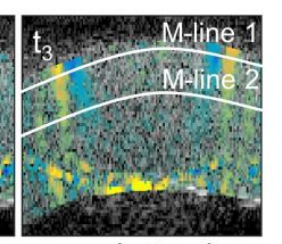

Lateral

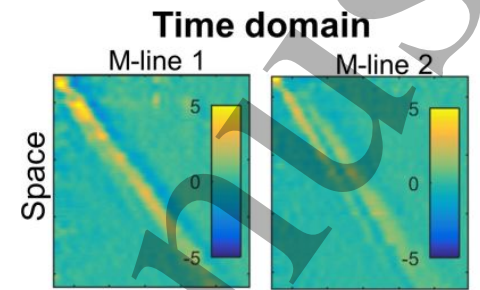

Time

Time
Frequency domain

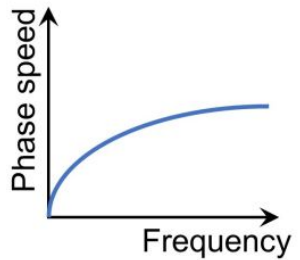

Figure 6 - Effect of geometry on shear wave properties. (a) Principle of waveguide. (b) Example of shear wave propagation in a left ventricular phantom. The two M-modes show that the shear wave propagation pattern in the time domain depends on the chosen depth. The frequency characteristics demonstrate an increasing phase speed as a function of frequency, even under the assumption of pure elasticity (no viscosity). Adapted with permission from Caenen et al. (Caenen et al., 2017).

\section{Viscosity}

Viscosity leads to absorption of the mechanical wave energy due to viscous friction, resulting in attenuation of the wave's amplitude. The viscosity-related attenuation increases with frequency, leading to a smoothed wave shape by removal of the high frequencies as shown in the Figure 5 (Bercoff et al., 2004). This comes together with an apparent stiffening of the material with increasing frequency, which in turn leads to a frequency-increasing phase speed, as is conceptually illustrated in Figure 7. The range of speeds that is reported by various studies is summarized in Table 2. Often a Voigt model is assumed to describe the relationship between shear wave speed dispersion and the material parameters (Nightingale et al., 2015), for which the dispersion relation is given by

$$
c(\omega)=\sqrt{\frac{2\left(\mu^{2}+\omega^{2} \eta^{2}\right)}{\rho\left(\mu+\sqrt{\mu^{2}+\omega^{2} \eta^{2}}\right)}}
$$

with propagation speed $c(\omega)$, angular frequency $\omega$, shear modulus $\mu$ and shear viscosity $\eta$ (see Figure 7). Some studies used this frequency-dependency to estimate myocardial viscoelasticity (Kanai, 2005; Urban et al., 2013; Nenadic et al., 2018; Pislaru et al., 2014b), which might provide additional diagnostic value next to elasticity (Sugimoto et al., 2020). For further details on this type of material characterization, we refer the reader to the appendix. 


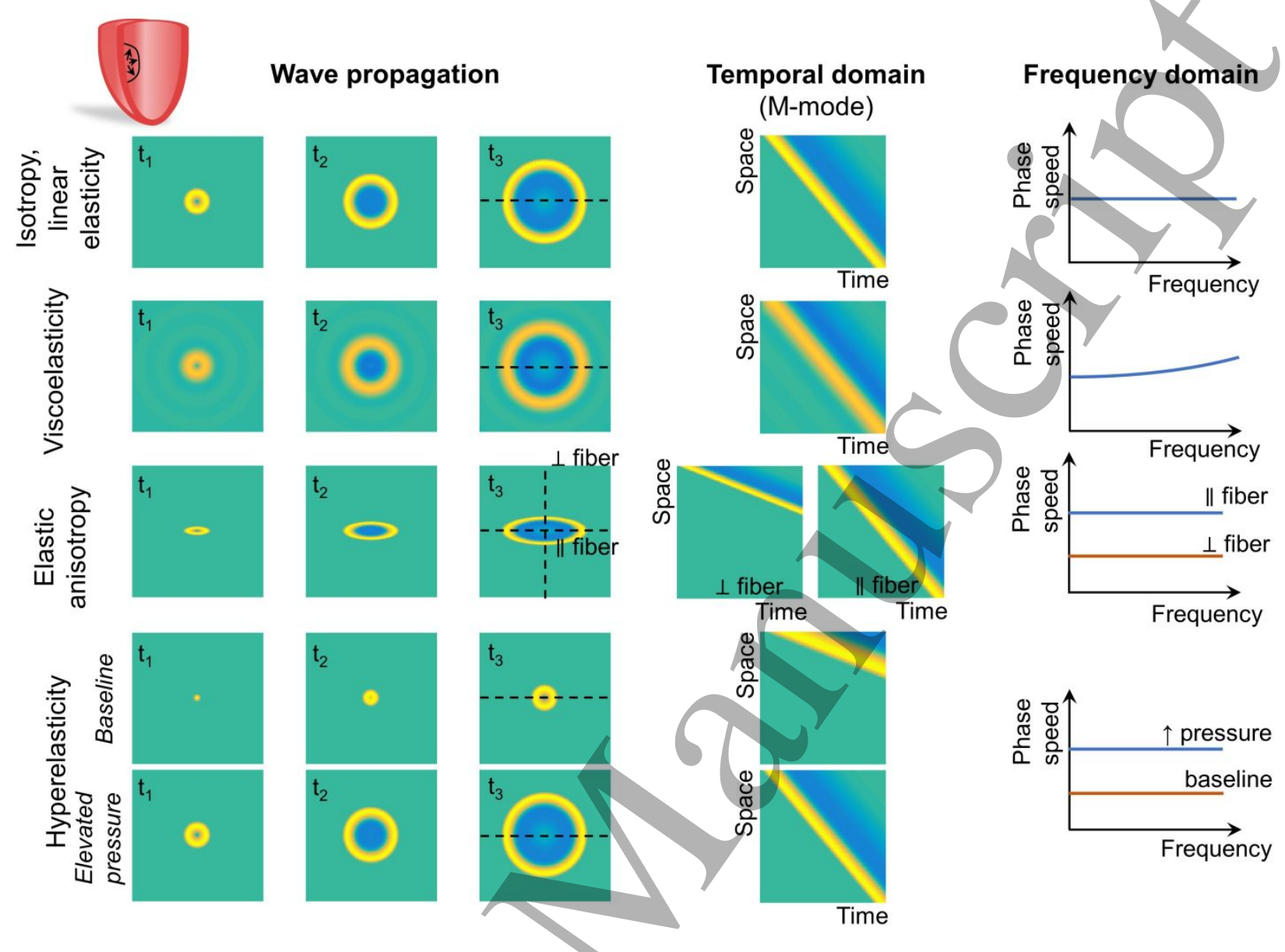

Figure 7 - Conceptual representation of the effect of viscoelasticity, elastic anisotropy and hyperelasticity on shear wave propagation, temporal and frequency characteristics.

\section{Anisotropy}

It is known from physics that shear waves propagate faster along the fiber than across due to elastic anisotropy, resulting in an elliptical shaped propagation pattern (Wang et al., 2013) (see Figure 5 and Figure 7). The myocardial fiber architecture is however complex: it follows a helical arrangement and it varies transmurally. For the sake of simplicity, however, many studies have assumed that the myocardium is locally transverse isotropic, with a symmetry axis along the local direction of fiber, resulting in a transmural varying wave directionality parallel to the cardiac wall (see Figure $8 a$ and Table 2). Note that the polarization direction of the shear wave with respect to the fiber orientation is also important. For example for an incompressible transverse isotropic medium such as skeletal muscle, two shear wave modes traveling at different speeds are possible: a shear horizontal mode, for which the wave propagation vector is perpendicular to the plane formed by the material symmetry axis and wave propagation direction, and a shear vertical mode, for which the wave propagation vector is parallel to the plane formed by the material symmetry axis and wave propagation direction (Rouze et al., 2013; Knight et al., 2021). These are also called slow and fast shear waves. 
The anisotropy in shear wave propagation has been assessed by analyzing the transmural wave speed variations in 3D (see Figure $8 \mathrm{~b}$ ) or in two echocardiographic views (Figure 8c). For example, wave speed in PSAX is higher than in PLAX at the mid cardiac wall for both ARFinduced (Villemain et al., 2018) and natural waves (Papadacci et al., 2020). Some studies have used this anisotropy in wave propagation to extract the myocardial fiber orientation, which agreed well with histology (Lee et al., 2012b) and magnetic resonance diffusion tensor imaging (Lee et al., 2012a). Other studies suggest that anisotropy of wave propagation offers additional diagnostic value (Villemain et al., 2018). In that respect, Couade et al. (Couade et al, 2011) introduced a new parameter, called fractional anisotropy (FA), to estimate the degree of anisotropy:

$$
F A=\frac{\sqrt{\left(v_{P S A X}-\bar{v}\right)^{2}+\left(v_{P L A X}-\bar{v}\right)^{2}}}{\sqrt{v_{P S A X}^{2}-v_{P L A X}^{2}}}
$$

With $v_{P S A X}$ the speed in PSAX, $v_{P L A X}$ the speed in PLAX and $\bar{v}$ the average of $v_{P S A X}$ and $v_{P L A X}$. FA can be calculated at any transmural depth, as shown in Figure 8c for the LV free wall in an openchest sheep in diastole and systole (Couade et al., 2011). Villemain et al. (Villemain et al., 2018) reported a FA of $0.238 \pm 0.068$ for the mid cardiac wall in healthy volunteers, and a decreased FA of $0.133 \pm 0.073$ in patients with hypertrophic cardiomyopathy (HCM).

a.

Anisotropic shear wave propagation in cardiac SWE simulations:

shear wave pattern and 3D shear wave propagation speed map
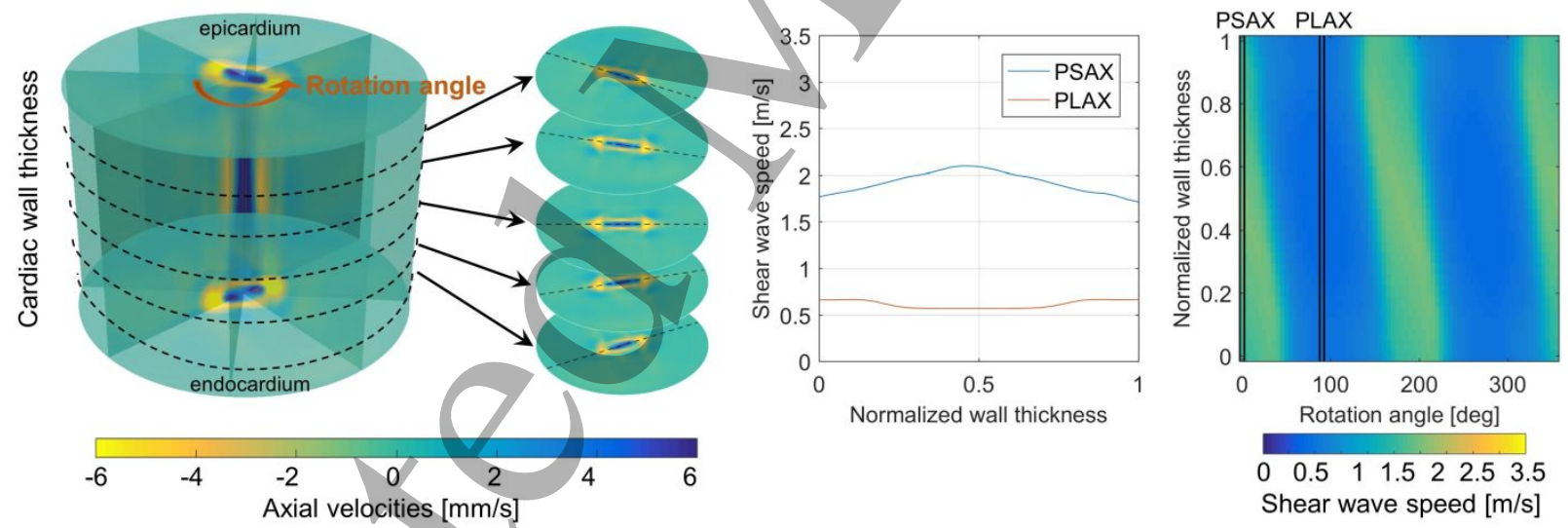

b. Shear wave propagation in in vivo open-chest sheep:

Diastolic and systolic shear wave propagation speed in PLAX and PSAX
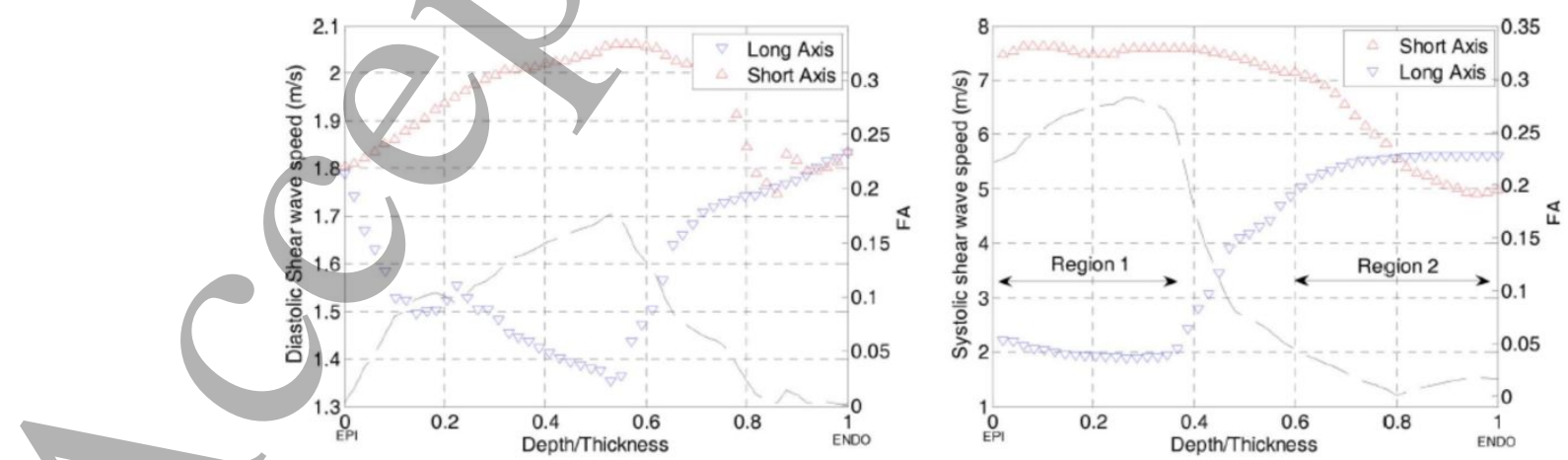
Figure 8 - Effect of anisotropy on shear wave properties for ARF-induced shear waves. (a) Demonstration of the ellipsoidal wave propagation patterns for various slices across cardiac wall thickness in a computer model of cardiac SWE (Caenen et al., 2018). The black dotted line in the slices represents the actual myocardial fiber orientation in the model. A shear wave propagation speed map can be obtained when analyzing the wave propagation for every angle in each transmural slice. The maximal speed in this map corresponds approximately to the myocardial fiber orientation (Caenen et al., 2018). Adapted with permission from Caenen et al. (Caenen et al., 2018). (b) Transmural shear wave speed and fractional anisotropy variations in diastole and systole of the LVFW of an open-chest sheep. Adapted with permission from Couade et al. (Couade et al., 2011).

\section{Contraction/relaxation}

Besides passive material properties, cardiac contraction affects shear wave speed measurements (see Table 2), providing opportunities for assessing time-varying muscle stiffness and, hence, myocardial contractility. Indeed, Bézy et al. (Bezy et al., 2020a) found a positive linear correlation between the wave speed after AVC and end-systolic elastance $(R=0.640 ; p<0.001)$ after dobutamine administration and bicycle exercise. Application of ARF-based SWE in a Langendorff animal heart set-up allowed to relate the shear wave speed in systole to the inotropic state of the heart in an unloaded condition: systolic shear stiffness was linearly correlated to coronary perfusion pressure (slope of $0.27 \mathrm{kPa} / \mathrm{mmHg}$ or, recalculating to shear wave speed ${ }^{1}$, $0.52 \mathrm{~m} / \mathrm{s} / \mathrm{mmHg} ; \mathrm{R}^{2}=0.73$ (Vejdani-Jahromi et al., 2017)) and to systolic pressure during administration of isoproterenol $\left(R^{2}=0.94-0.98\right.$; $p<0.0001$ (Pernot et al., 2011)). Furthermore, repeated application of ARF-based SWE throughout the cardiac cycle allows to capture the dynamic stiffness variations (see Figure 9c). Two studies of the same authors (Vejdani-Jahromi et al., 2018; Vejdani-Jahromi et al., 2016) have used the wave speed variations during the isovolumic relaxation phase to estimate the relaxation time constant of diastolic function. The researchers reported an average time constant of $65 \pm 19 \mathrm{~ms}$ for 8 Langendorff perfused rabbit hearts, which increased to $154 \pm 60 \mathrm{~ms}$ after Ml induction. Furthermore, a linear regression model demonstrated the similarity between the relaxation time constant obtained from the LV pressure curve and the ARF-based shear wave speed curve (slope=1.164; $\mathrm{R}^{2}=0.8$ (Vejdani-Jahromi et al., 2018)).

It should, nonetheless, be noted that the timing of the mechanical waves after valve closure within the isovolumic contraction/relaxation phase is unclear. Recent work combining ARF-based and natural SWE (Keijzer et al., 2020a) was able to detect both wave types in the same acquisition as visualized in Figure $9 a$ and $b$. This permitted to investigate the timing of natural wave measurements with respect to ARF-assessed cardiac dynamics: waves after valve closure occurred when the myocardium is in between relaxation and contraction (Figure 9c). Additionally, this figure shows a good match in propagation speeds between natural and ARF-based SWE at the moment of valve closure, despite the clear differences in wavelength (a few $\mathrm{mm}$ vs. a few $\mathrm{cm}$ ) and wave amplitude (a few $\mathrm{mm} / \mathrm{s}$ vs. tens $\mathrm{mm} / \mathrm{s}$ ) (Figure 9a-b). This result shows that many factors, such as fluid loading, contraction speed, contraction synchronicity, or even stenosis of outflow track on mitral valve, can affect the exact moment of valve closure, and hence the instantaneous speed of the induced wave.

\footnotetext{
1 Recalculated from equation (1) while assuming a density of $1000 \mathrm{~kg} / \mathrm{m}^{3}$.
} 


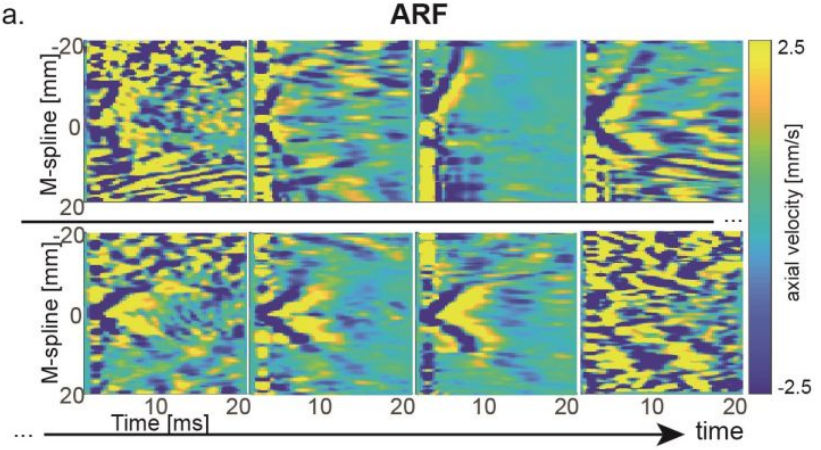

b.

Valve closure
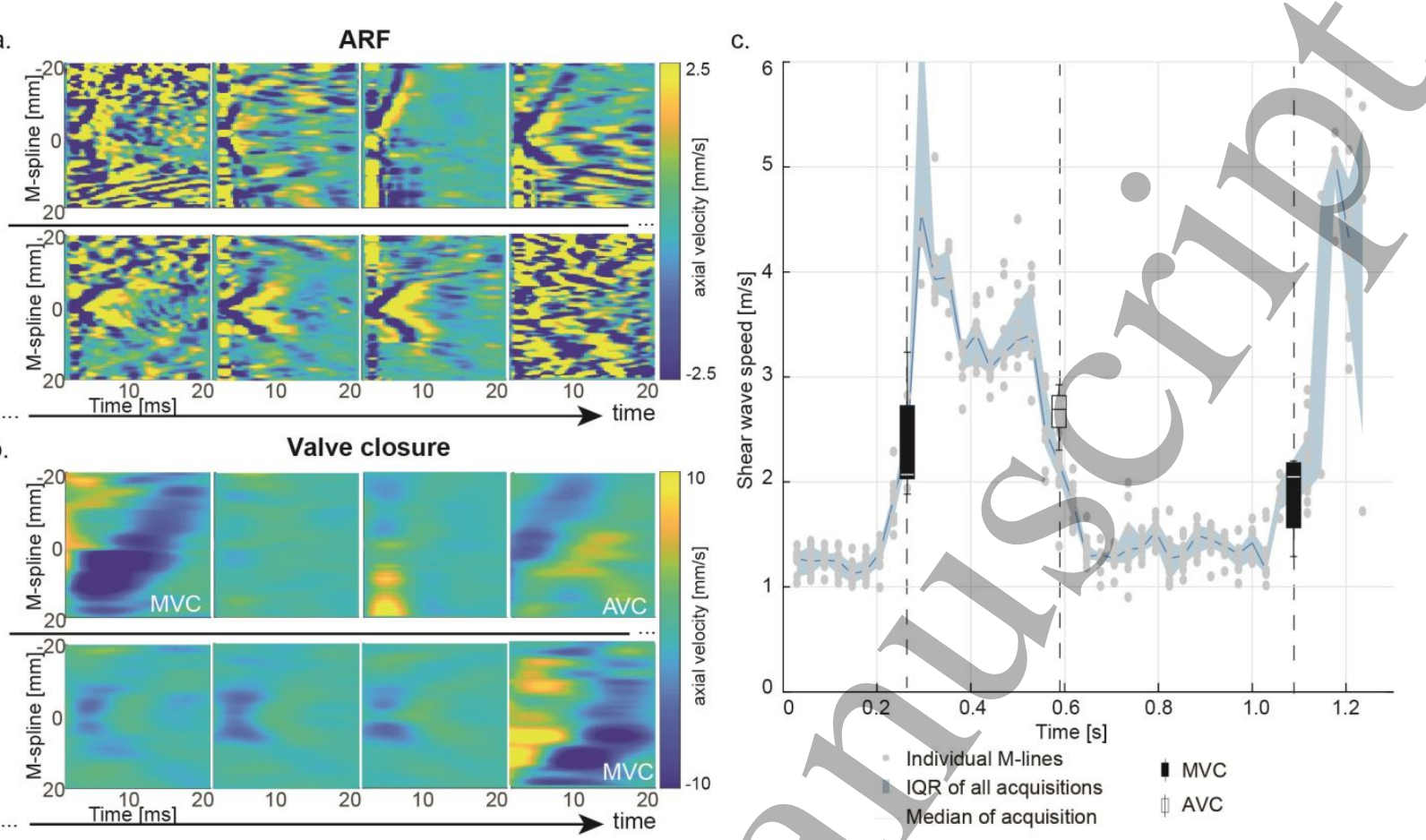

Figure 9 - Shear wave propagation throughout the cardiac cycle in a pig's septal wall. Two types of shear waves are visible in the same SWE acquisition: shear waves induced with an acoustic radiation force (ARF; panel a) and by valve closure (VC; panel b). Panel c demonstrated the estimated shear wave speeds for both techniques. Adapted with permission from Keijzer and Caenen et al. (Keijzer et al., 2020a).

\section{Hemodynamics}

Altering preload or afterload affects the magnitude of the pressure acting on the cardiac wall, and thus the stress/strain state in the ventricle because of the material's hyperelasticity (see Figure $1 \mathrm{~b}$ and Figure 7). Table 2 quantifies the effect of changing loading condition on the wave speeds. A negligible change in diastolic wave speed was reported for ARF-based SWE $(\Delta 0.04 \mathrm{~m} / \mathrm{s}$ for $\triangle$ EDP of $14.7 \mathrm{mmHg}$ (Pernot et al., 2011) and $\Delta 0.5 \mathrm{kPa}$ for $\triangle$ EDP of $5 \mathrm{mmHg}$ (Pislaru et al., 2014b)), whereas the wave speed after MVC increased significantly with increased EDP $(\Delta 4.9$ $\mathrm{m} / \mathrm{s}$ for $\triangle E D P$ of $21.7 \mathrm{mmHg}: \mathrm{R}=0.83$ and $\mathrm{p}<0.001$ (Bezy et al., 2020b)). Differences in shear wave excitation properties, experimental set-up and investigated pressure range partly explain the reported difference in the sensitivity of shear wave speed to pressure, but more importantly, the end-diastolic moment of the shear wave recording for ARF-based SWE might still be in the quasi-linear part of the stress-strain relationship whereas this might be different for the shear wave after MVC for which, again, the exact timing within the isovolumic contraction phase is unclear (Keijzer et al., 2020a; Pernot and Villemain, 2019).

\section{Pathology}

Most literature on SWE in pathology is obtained in animal models (Pernot et al., 2016; Couade et al., 2011; Pislaru et al., 2014b) by inducing a myocardial infarction (MI) through ligation of a coronary artery using ARF-based SWE. Studies have consequently reported an increase in diastolic wave speed following MI (range of $\Delta 0.11-2.18 \mathrm{~m} / \mathrm{s}$ for all studies; Table 2), of which its 
magnitude depended on the duration of ligation (15-120 minutes) and reperfusion (40-120 minutes). A short term ligation of 15 minutes did not affect diastolic wave speed permanently (Couade et al., 2011; Pernot et al., 2016). The increase in diastolic wave speed after MI was validated, by comparison with several invasive measurements: (i) an increase in the exponential coefficient of the end-diastolic pressure volume relationship (4.027 vs. $2.010 \mathrm{ml}^{-1}$ ) (VejdaniJahromi et al., 2018), (ii) an increase in the exponential coefficient of the end diastolic strainstress relationship measured with sonomicrometry (25.7 \pm 9.5 vs. 8.8 \pm 2.3 ) (Pernot et al., 2016) and (iii) an increase in the shear modulus obtained with the pressure-segment length method $(9.4 \pm 4.9 \mathrm{kPa}$ vs. $1.9 \pm 0.5 \mathrm{kPa}$ ) (Pislaru et al., 2014b). Fewer studies (Hollender et al., 2013; Couade et al., 2011; Pislaru et al., 2014b) also investigated the effect of MI on systolic wave speed, but the results are inconclusive.

Cardiac pathology might be associated with other changes next to an increased wall stiffness such as an increased wall thickness (hypertrophy), a change in viscosity and fiber disarray especially when tissue remodeling and fibrosis occurs. Conceptually, more parameters than shear wave speed are necessary to completely describe the effect of pathology, but the clinical relevance of additional parameters needs further investigation. For example, Pislaru et al. (Pislaru et al., 2014b) showed an increase in elasticity and viscoelasticity at end-diastole after reperfusion, whereas less consistent changes were found during systole.

Table 2 - Overview of (pre)clinical feasibility studies that have investigated the effect of one or more mechanical factors on wave propagation speed (ARF: acoustic radiation force; EDP: end-diastolic pressure; ESP: end-systolic pressure; FFT: fast Fourier transform; ICE: intracardiac echocardiography; LAD: left anterior descending coronary artery; LCX: left circumflex coronary artery; MI: myocardial infarct; MS: mechanical stimulation; VC: valve closure; LVFW: left ventricular free wall; other abbreviations are as listed in Table 1).

\begin{tabular}{|c|c|c|c|c|c|c|}
\hline & \multirow[b]{2}{*}{$\begin{array}{l}\text { Study description } \\
\text { (ref \#) }\end{array}$} & \multicolumn{5}{|c|}{ Study set-up/results } \\
\hline & & \begin{tabular}{|l|} 
Excit \\
ation \\
\end{tabular} & Region & Species & $\begin{array}{l}\text { Diastolic wave speed } \\
{[\mathrm{m} / \mathrm{s}]}\end{array}$ & $\begin{array}{c}\text { Systolic wave speed } \\
{[\mathrm{m} / \mathrm{s}]}\end{array}$ \\
\hline$\frac{\vec{T}}{\mathrm{C}}$ & $\begin{array}{l}\text { Analyze frequency } \\
\text { content using FFT } \\
\text { (Nenadic et al., 2018) }\end{array}$ & ARF & LVFW & $\begin{array}{l}\text { Open-chest } \\
\text { pig }(n=1)\end{array}$ & NR & $\begin{array}{l}2.2 \mathrm{~m} / \mathrm{s} \text { at } 100 \mathrm{~Hz} \text { to } \\
4.8 \mathrm{~m} / \mathrm{s} \text { at } 500 \mathrm{~Hz}\end{array}$ \\
\hline 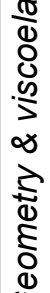 & $\begin{array}{l}\text { Determine phase speed at } \\
\text { various frequencies } \\
\text { (Urban et al., 2013) }\end{array}$ & $M$ & (ᄃ & $\begin{array}{l}\text { Open-chest } \\
\text { pigs }(n=8)\end{array}$ & $\begin{array}{l}1.1 \pm 0.2 \mathrm{~m} / \mathrm{s} \text { at } 50 \mathrm{~Hz} \\
1.5 \pm 0.3 \mathrm{~m} / \mathrm{s} \text { at } 100 \mathrm{~Hz} \\
1.6 \pm 0.4 \mathrm{~m} / \mathrm{s} \text { at } 150 \mathrm{~Hz} \\
1.7 \pm 0.2 \mathrm{~m} / \mathrm{s} \text { at } 200 \mathrm{~Hz} \\
2.1 \pm 0.5 \mathrm{~m} / \mathrm{s} \text { at } 250 \mathrm{~Hz} \\
2.4 \pm 0.4 \mathrm{~m} / \mathrm{s} \text { at } 300 \mathrm{~Hz} \\
2.5 \pm 0.5 \mathrm{~m} / \mathrm{s} \text { at } 350 \mathrm{~Hz}\end{array}$ & $\begin{array}{l}3.2 \pm 0.9 \mathrm{~m} / \mathrm{s} \text { at } 50 \mathrm{~Hz} \\
3.0 \pm 0.6 \mathrm{~m} / \mathrm{s} \text { at } 100 \mathrm{~Hz} \\
3.3 \pm 0.5 \mathrm{~m} / \mathrm{s} \text { at } 150 \mathrm{~Hz} \\
3.8 \pm 0.6 \mathrm{~m} / \mathrm{s} \text { at } 200 \mathrm{~Hz} \\
4.2 \pm 0.6 \mathrm{~m} / \mathrm{s} \text { at } 250 \mathrm{~Hz} \\
4.5 \pm 0.9 \mathrm{~m} / \mathrm{s} \text { at } 300 \mathrm{~Hz} \\
5.0 \pm 1.2 \mathrm{~m} / \mathrm{s} \text { at } 350 \mathrm{~Hz}\end{array}$ \\
\hline ర) & $\begin{array}{l}\text { Determine phase speed at } \\
\text { various frequencies } \\
\text { (Pislaru et al., 2014b) }\end{array}$ & MS & LVFW & $\begin{array}{l}\text { Open-chest } \\
\text { pigs }(n=10)\end{array}$ & $\begin{array}{l}1.4 \pm 0.4 \mathrm{~m} / \mathrm{s} \text { at } 100 \mathrm{~Hz} \\
1.5 \pm 0.5 \mathrm{~m} / \mathrm{s} \text { at } 150 \mathrm{~Hz} \\
1.6 \pm 0.2 \mathrm{~m} / \mathrm{s} \text { at } 200 \mathrm{~Hz} \\
2.1 \pm 0.5 \mathrm{~m} / \mathrm{s} \text { at } 250 \mathrm{~Hz} \\
2.4 \pm 0.3 \mathrm{~m} / \mathrm{s} \text { at } 300 \mathrm{~Hz} \\
2.5 \pm 0.5 \mathrm{~m} / \mathrm{s} \text { at } 350 \mathrm{~Hz}\end{array}$ & $\begin{array}{l}3.1 \pm 0.5 \mathrm{~m} / \mathrm{s} \text { at } 100 \mathrm{~Hz} \\
3.8 \pm 1.6 \mathrm{~m} / \mathrm{s} \text { at } 150 \mathrm{~Hz} \\
4.4 \pm 2.0 \mathrm{~m} / \mathrm{s} \text { at } 200 \mathrm{~Hz} \\
4.1 \pm 0.6 \mathrm{~m} / \mathrm{s} \text { at } 250 \mathrm{~Hz} \\
4.4 \pm 1.0 \mathrm{~m} / \mathrm{s} \text { at } 300 \mathrm{~Hz} \\
4.8 \pm 1.3 \mathrm{~m} / \mathrm{s} \text { at } 350 \mathrm{~Hz}\end{array}$ \\
\hline & \begin{tabular}{|l|} 
Analyze frequency \\
content using FFT (Kanai, \\
2005)
\end{tabular} & VC & IVS & $\begin{array}{c}\text { Human } \\
(n=5)\end{array}$ & NR & $\begin{array}{l}1-2 \mathrm{~m} / \mathrm{s} \text { at } 20 \mathrm{~Hz} \\
3-4 \mathrm{~m} / \mathrm{s} \text { at } 50 \mathrm{~Hz} \\
3-7 \mathrm{~m} / \mathrm{s} \text { at } 90 \mathrm{~Hz}\end{array}$ \\
\hline & $\begin{array}{l}\text { Analyze frequency } \\
\text { content using FFT (Vos et } \\
\text { al., 2017) }\end{array}$ & VC & IVS & Pig $(n=22)$ & $\begin{array}{l}2.0 \mathrm{~m} / \mathrm{s} \text { at } 15-45 \mathrm{~Hz} \\
2.6 \mathrm{~m} / \mathrm{s} \text { at } 45-75 \mathrm{~Hz} \\
3.8 \mathrm{~m} / \mathrm{s} \text { at } 75-110 \mathrm{~Hz} \\
3.4 \mathrm{~m} / \mathrm{s} \text { at } 110-150 \mathrm{~Hz}\end{array}$ & $\begin{array}{l}3.8 \mathrm{~m} / \mathrm{s} \text { at } 15-45 \mathrm{~Hz} \\
3.8 \mathrm{~m} / \mathrm{s} \text { at } 45-75 \mathrm{~Hz} \\
4.4 \mathrm{~m} / \mathrm{s} \text { at } 75-110 \mathrm{~Hz} \\
4.1 \mathrm{~m} / \mathrm{s} \text { at } 110-150 \mathrm{~Hz}\end{array}$ \\
\hline
\end{tabular}




\begin{tabular}{|c|c|c|c|c|c|c|}
\hline$\frac{2}{2}$ & $\begin{array}{l}\text { Analyze different depths } \\
\text { and views (Couade et al., } \\
\text { 2011) }\end{array}$ & ARF & LVFW & $\begin{array}{l}\text { Open-chest } \\
\text { sheep } \\
(n=10)\end{array}$ & $\begin{array}{l}\text { Mid: } 1.5 \pm 0.3 \mathrm{~m} / \mathrm{s} \text { in PLAX; } \\
1.9 \pm 0.2 \mathrm{~m} / \mathrm{s} \text { in PSAX } \\
\text { Epi: } 1.8 \mathrm{~m} / \mathrm{s} \text { in PLAX and } \\
\text { PSAX } \\
\text { Endo: } 1.8 \mathrm{~m} / \mathrm{s} \text { in PSAX and } \\
\text { PSAX }\end{array}$ & $\begin{array}{l}\text { Mid: } 4.8 \pm 1.4 \mathrm{~m} / \mathrm{s} \text { in PLAX; } \\
6.2 \pm 1.9 \mathrm{~m} / \mathrm{s} \text { in PSAX } \\
\text { Epi: } 2.2 \mathrm{~m} / \mathrm{s} \text { in PLAX; } 7.4 \\
\mathrm{~m} / \mathrm{s} \text { in PSAX } \\
\text { Endd: } 5.7 \mathrm{~m} / \mathrm{s} \text { in PLAX; } 5.0 \\
\mathrm{~m} / \mathrm{s} \text { in } P S A X\end{array}$ \\
\hline & $\begin{array}{l}\text { Analyze PSAX and PLAX } \\
\text { (Villemain et al., 2018) }\end{array}$ & ARF & IVS & $\begin{array}{l}\text { Human } \\
(n=60)\end{array}$ & $\begin{array}{l}1.54 \pm 0.26 \mathrm{~m} / \mathrm{s} \text { in PLAX } \\
2.16 \pm 0.42 \mathrm{~m} / \mathrm{s} \text { in PSAX }\end{array}$ & \\
\hline & $\begin{array}{l}\text { Analyze different axial and } \\
\text { lateral locations } \\
\text { (Bouchard et al., 2009) }\end{array}$ & ARF & LVFW & $\begin{array}{l}\text { Open-chest } \\
\text { dog }(n=1)\end{array}$ & $\begin{array}{l}0.82-2.65 \mathrm{~m} / \mathrm{s} \text { depending on } \\
\text { location }\end{array}$ & $N R$ \\
\hline & $\begin{array}{l}\text { Analyze different axial and } \\
\text { lateral locations (Keijzer et } \\
\text { al., 2018) }\end{array}$ & VC & IVS & $\begin{array}{l}\text { Open-chest } \\
\text { pigs }(n=3)\end{array}$ & NR & $\begin{array}{l}5.7-10.1 \mathrm{~m} / \mathrm{s} \text { depending on } \\
\text { location }\end{array}$ \\
\hline & $\begin{array}{l}\text { Analyze wave propagation } \\
\text { in 3D (Papadacci et al., } \\
\text { 2020) }\end{array}$ & VC & IVS & $\begin{array}{c}\text { Human } \\
(n=3)\end{array}$ & $\begin{array}{l}2.8 \pm 0.5 \mathrm{~m} \\
4.6 \pm 0.7 \mathrm{~m}\end{array}$ & $\begin{array}{l}3.4 \pm 0.1 \mathrm{~m} / \mathrm{s} \text { in PLAX } \\
3.5 \pm 0.3 \mathrm{~m} / \mathrm{s} \text { in PSAX } \\
\text { antero-septal } \\
5.4 \pm 0.7 \mathrm{~m} / \mathrm{s} \text { in PSAX } \\
\text { postero-septal }\end{array}$ \\
\hline & $\begin{array}{l}\text { Administer isoproterenol } \\
\left(10^{-8} \mathrm{~mol} / \mathrm{l}\right) \text { (Pernot et al., } \\
2011)\end{array}$ & ARF & LVFW & $\begin{array}{l}\text { Langendorff } \\
\text { rat }(n=6)\end{array}$ & NR & $\begin{array}{l}\text { Pre: } 3.18 \mathrm{~m} / \mathrm{s} \\
\text { Post: } 4.84 \mathrm{~m} / \mathrm{s}\end{array}$ \\
\hline 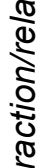 & $\begin{array}{l}\text { Changing Krebs } \\
\text { extracellular calcium } \\
\text { concentration (Pernot et } \\
\text { al., 2011) }\end{array}$ & ARF & LVFW & $\begin{array}{l}\text { Langendorff } \\
\text { rat }(n=6)\end{array}$ & $\begin{array}{l}0.8 \mathrm{mMol}: 1.00 \mathrm{~m} / \mathrm{s} \\
1.8 \mathrm{mMol}: 1.01 \mathrm{~m} / \mathrm{s} \\
2.5 \mathrm{mMol}: 1.01 \mathrm{~m} / \mathrm{s}\end{array}$ & $\begin{array}{l}0.8 \mathrm{mMol}: 1.66 \mathrm{~m} / \mathrm{s} \\
1.8 \mathrm{mMol}: 2.95 \mathrm{~m} / \mathrm{s} \\
2.5 \mathrm{mMol}: 3.61 \mathrm{~m} / \mathrm{s}\end{array}$ \\
\hline ठ & $\begin{array}{l}\text { Alter coronary perfusion } \\
\text { pressure }(0-90 \mathrm{mmHg}) \\
\text { (Vejdani-Jahromi et al., } \\
\text { 2015) }\end{array}$ & ARF & LVFW & $\begin{array}{l}\text { Langendorff } \\
\text { rabbit }(n=8)\end{array}$ & $\begin{array}{l}1.36 \pm 0.08 \mathrm{~m} / \mathrm{s} \text { at } 0 \mathrm{mmHg} \\
1.58 \pm 0.05 \mathrm{~m} / \mathrm{s} \text { at } 25 \mathrm{mmHg} \\
1.84 \pm 0.05 \mathrm{~m} / \mathrm{s} \text { at } 50 \mathrm{mmHg} \\
2.03 \pm 0.05 \mathrm{~m} / \mathrm{s} \text { at } 75 \mathrm{mmHg} \\
2.34 \pm 0.15 \mathrm{~m} / \mathrm{s} \text { at } 90 \mathrm{mmHg}\end{array}$ & NR \\
\hline & $\begin{array}{l}\text { Alter coronary perfusion } \\
\text { pressure }(0-90 \mathrm{mmHg}) \\
\text { (Vejdani-Jahromi et al., } \\
2017)\end{array}$ & ARF & LVFW & $\begin{array}{l}\text { Langendorff } \\
\text { rabbit }(n=12)\end{array}$ & NR & $\begin{array}{l}3.16 \mathrm{~m} / \mathrm{s} \text { at } 0 \mathrm{mmHg} \\
4.09 \mathrm{~m} / \mathrm{s} \text { at } 25 \mathrm{mmHg} \\
4.85 \mathrm{~m} / \mathrm{s} \text { at } 50 \mathrm{mmHg} \\
5.50 \mathrm{~m} / \mathrm{s} \text { at } 75 \mathrm{mmHg} \\
5.86 \mathrm{~m} / \mathrm{s} \text { at } 90 \mathrm{mmHg} \\
\end{array}$ \\
\hline & $\begin{array}{l}\text { Perform dobutamine } \\
\text { stress test (Santos et al., } \\
\text { 2018) }\end{array}$ & & & $\begin{array}{c}\text { Human } \\
(\mathrm{n}=1)\end{array}$ & $\begin{array}{l}\text { Pre: } 2.9 \mathrm{~m} / \mathrm{s} \\
10 \mu \mathrm{g} /(\mathrm{kg} \cdot \mathrm{min}): 15.5 \mathrm{~m} / \mathrm{s} \\
40 \mu \mathrm{g} /(\mathrm{kg} \cdot \min ): 19.7 \mathrm{~m} / \mathrm{s}\end{array}$ & NR \\
\hline & $\begin{array}{l}\text { Perform supine bicycle } \\
\text { exercise test (66 \% work } \\
\text { load) (Bezy et al., 2020a) }\end{array}$ & & VS & $\begin{array}{l}\text { Human } \\
(n=11)\end{array}$ & NR & $\begin{array}{l}\text { Pre: } 3.3 \pm 0.5 \mathrm{~m} / \mathrm{s} \\
\text { Post: } 6.2 \pm 1.7 \mathrm{~m} / \mathrm{s}\end{array}$ \\
\hline & $\begin{array}{l}\text { Perform dobutamine } \\
\text { stress test (Bezy et al., } \\
\text { 2020a) }\end{array}$ & VC & IVS & $\begin{array}{c}\text { Human } \\
(n=9)\end{array}$ & NR & $\begin{array}{l}\text { Pre: } 4.4 \pm 0.6 \mathrm{~m} / \mathrm{s} \\
40 \mu \mathrm{g} /(\mathrm{kg} \cdot \mathrm{min}): 7.2 \pm 1.7 \mathrm{~m} / \mathrm{s}\end{array}$ \\
\hline 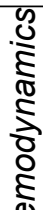 & $\begin{array}{l}\text { Increase preload (EDP: } \\
5.8 \pm 0.7 \text { to } 20.5 \pm 6.9 \\
\text { mmHg; ESP: } 72 \pm 7.4 \text { to } \\
124.7 \pm 13.5 \mathrm{mmHg} \text { ) } \\
\text { (Pernot et al., } 2011)\end{array}$ & ARF & LVFW & $\begin{array}{l}\text { Langendorff } \\
\text { rat }(n=6)\end{array}$ & $\begin{array}{l}\text { Pre: } 1.30 \mathrm{~m} / \mathrm{s} \\
\text { Post: } 1.34 \mathrm{~m} / \mathrm{s} \\
(\Delta+0.04 \mathrm{~m} / \mathrm{s})\end{array}$ & $\begin{array}{l}\text { Pre: } 3.18 \mathrm{~m} / \mathrm{s} \\
\text { Post: } 3.51 \mathrm{~m} / \mathrm{s} \\
(\Delta+0.33 \mathrm{~m} / \mathrm{s})\end{array}$ \\
\hline$\stackrel{0}{I}$ & $\begin{array}{l}\text { Reduce preload ( } \triangle \mathrm{EDP}=- \\
10.1 \pm 2.5 \mathrm{mmHg} \text { ) (Bezy et } \\
\text { al., } 2020 \mathrm{~b} \text { ) }\end{array}$ & VC & IVS & Pigs $(n=5)$ & $\Delta-1.2 \pm 1.4 \mathrm{~m} / \mathrm{s}$ & NR \\
\hline
\end{tabular}




\begin{tabular}{|c|c|c|c|c|c|}
\hline $\begin{array}{l}\text { Increase preload ( } \triangle \mathrm{EDP}= \\
+2.3 \pm 2.7 \mathrm{mmHg}) \text { (Bezy et } \\
\text { al., 2020b) }\end{array}$ & VC & IVS & Pigs $(n=5)$ & $\Delta+2.0 \pm 0.8 \mathrm{~m} / \mathrm{s}$ & NR \\
\hline $\begin{array}{l}\text { Induce } \mathrm{Ml} \text { by } 1-3 \mathrm{~h} \text { ligation } \\
\text { of mid to distal LAD and } \\
1-2 \mathrm{~h} \text { reperfusion (Pislaru } \\
\text { et al., 2014b) }\end{array}$ & MS & LVFW & $\begin{array}{l}\text { Open-chest } \\
\text { pigs }(n=10)\end{array}$ & $\begin{array}{l}2.7 \pm 1.0 \mathrm{~m} / \mathrm{s} \text { at } 100 \mathrm{~Hz} \\
2.9 \pm 0.7 \mathrm{~m} / \mathrm{s} \text { at } 150 \mathrm{~Hz} \\
3.3 \pm 1.3 \mathrm{~m} / \mathrm{s} \text { at } 200 \mathrm{~Hz} \\
3.5 \pm 1.1 \mathrm{~m} / \mathrm{s} \text { at } 250 \mathrm{~Hz} \\
3.4 \pm 0.6 \mathrm{~m} / \mathrm{s} \text { at } 300 \mathrm{~Hz} \\
3.4 \pm 0.8 \mathrm{~m} / \mathrm{s} \text { at } 350 \mathrm{~Hz}\end{array}$ & $\begin{array}{l}5.4 \pm 2.4 \mathrm{~m} / \mathrm{s} \text { at } 100 \mathrm{~Hz} \\
4.6 \pm 1.4 \mathrm{~m} / \mathrm{s} \text { at } 150 \mathrm{~Hz} \\
4.8 \pm 0.8 \mathrm{~m} / \mathrm{s} \text { at } 200 \mathrm{~Hz} \\
5.6 \pm 0.6 \mathrm{~m} / \mathrm{s} \text { at } 250 \mathrm{~Hz} \\
5.0 \pm 0.6 \mathrm{~m} / \mathrm{s} \text { at } 300 \mathrm{~Hz} \\
5.6 \pm 1.0 \mathrm{~m} / \mathrm{s} \text { at } 350 \mathrm{~Hz}\end{array}$ \\
\hline $\begin{array}{l}\text { Induce } \mathrm{Ml} \text { by } 2 \mathrm{~h} \text { ligation of } \\
\mathrm{LAD} \text { diagonal branch and } \\
2 \mathrm{~h} \text { reperfusion (Pernot et } \\
\text { al., } 2016)\end{array}$ & ARF & LVFW & $\begin{array}{l}\text { Open-chest } \\
\text { sheep } \\
(n=10)\end{array}$ & $\begin{array}{l}\text { Pre: } 1.30 \mathrm{~m} / \mathrm{s} \\
\text { Post MI: } 2.49 \mathrm{~m} / \mathrm{s} \\
\text { Post reperfusion: } 3.48 \mathrm{~m} / \mathrm{s}\end{array}$ & NR \\
\hline $\begin{array}{l}\text { Induce MI by } 20 \text { min } \\
\text { ligation of LAD (Couade et } \\
\text { al., 2011) }\end{array}$ & ARF & LVFW & $\begin{array}{l}\text { Open-chest } \\
\text { sheep }(n=1)\end{array}$ & $\begin{array}{l}\text { Pre: } 1.5 \pm 0.1 \mathrm{~m} / \mathrm{s} \\
\text { Post } \mathrm{Ml}: 1.3 \pm 0.1 \mathrm{~m} / \mathrm{s}\end{array}$ & $\begin{array}{l}\text { Pre: } 6.0 \pm 0.2 \mathrm{~m} / \mathrm{s} \\
\text { Post Ml: } 1.3 \pm 0.1 \mathrm{~m} / \mathrm{s}\end{array}$ \\
\hline $\begin{array}{l}\text { Induce global MI by } \\
\text { stopping inflow perfusion } \\
\text { for } 10 \text { min and re-perfuse } \\
\text { heart for } 10 \text { min (Vejdani- } \\
\text { Jahromi et al., 2018) }\end{array}$ & ARF & LVFW & $\begin{array}{l}\text { Langendorff } \\
\text { rabbit }(n=11)\end{array}$ & $\begin{array}{l}\text { Pre: } 2.31 \mathrm{~m} / \mathrm{s} \\
\text { Post MI: } 3.29 \mathrm{~m} / \mathrm{s}\end{array}$ & NR \\
\hline
\end{tabular}

Derived from graph or calculated from text

Converted from stiffness to shear wave speed by using equation (1) and assuming a $\rho$ of $1000 \mathrm{~kg} / \mathrm{m}^{3}$

\section{Clinical application}

\section{Shear wave speeds in healthy volunteers and patients}

Various clinical studies have confirmed that mechanical factors do affect shear wave speed, and should be considered when interpreting SWE data. An overview is given in Table 3. Indeed, shear wave speed has been shown to significantly and positively correlate with ED wall thickness and with loading conditions (reflected by predictors E/e', pulmonary capillary wedge pressure, left atrial volume index or LA diameter). Additionally, a positive correlation was found between shear wave speed and age (Villemain et al., 2018; Cvijic et al., 2020; Bezy et al., 2020c). 
Table 3 - Summary of reported significant correlations between shear wave speed and parameters quantifying cardiac function in various clinical studies using univariate and multivariate analyses (ED: end diastolic; EDP: end diastolic pressure; HCM: hypertrophic cardiomyopathy; HT: hypertension; HTX: heart transplantation; HV: healthy volunteer; LA ø: left atrial diameter; LAVI: left atrial volume index; LGE: late gadolinium enhancement; LV: left ventricle; NS: not significant; PCWP: pulmonary capillary wedge pressure; other abbreviations are as listed in Tables 1 and 2).

\begin{tabular}{|c|c|c|c|c|c|c|c|c|}
\hline & \multirow{2}{*}{$\begin{array}{l}\text { Study } \\
\text { (ref \#) }\end{array}$} & \multirow{2}{*}{$\begin{array}{l}\text { Excit } \\
\text { ation }\end{array}$} & \multirow[b]{2}{*}{ Patient } & \multirow[b]{2}{*}{ Age } & \multirow{2}{*}{\begin{tabular}{c|} 
Geometry \\
ED wall \\
thickness
\end{tabular}} & \multicolumn{2}{|c|}{ Hemodynamics } & \multirow{2}{*}{ Pathology } \\
\hline & & & & & & LA size & LV EDP & \\
\hline \multirow{6}{*}{ 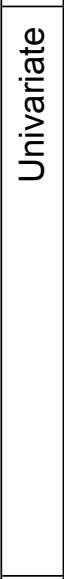 } & $\begin{array}{l}\text { (Villemain } \\
\text { et al., 2018) }\end{array}$ & ARF & $\mathrm{HV} \& \mathrm{HCM}$ & $R=0.881$ & NS & $\begin{array}{c}\text { LAVI: } \\
\mathrm{R}=0.623\end{array}$ & $\begin{array}{c}E / e^{\prime}: \\
R=0.783\end{array}$ & $\begin{array}{l}\text { LGE: } R=0.804 \\
\text { T1 pre-contrast: } \\
R=0.711\end{array}$ \\
\hline & $\begin{array}{l}\text { (Strachinaru } \\
\text { et al., } \\
\text { 2019a) }\end{array}$ & VC & $\mathrm{HV} \& \mathrm{HCM}$ & NS & NR & NR & $\begin{array}{c}\text { Ele': } \\
\text { AVC: } R=0.587^{*} \\
\text { MVC: } R=0.817^{*}\end{array}$ & NR \\
\hline & \begin{tabular}{|l} 
(Petrescu et \\
al., 2019)
\end{tabular} & MVC & HV \& amyloidosis & NR & NR & NR & $\begin{array}{c}\text { E/e': } \\
R=0.74\end{array}$ & NR \\
\hline & $\begin{array}{l}\text { (Petrescu et } \\
\text { al., 2020) } \\
\end{array}$ & MVC & HTX & NR & NR & TNe & $\begin{array}{l}\text { PCWP: } \\
R=0.54\end{array}$ & $\begin{array}{l}\text { Native T1: } \\
\mathrm{R}=0.75\end{array}$ \\
\hline & $\begin{array}{l}\text { (Cvijic et al., } \\
\text { 2020) }\end{array}$ & MVC & HV \& arterial HT & NR & $R=0.786$ & $\begin{array}{r}\text { LA ø: } \\
R=0.800\end{array}$ & $\begin{array}{c}\text { E/e': } \\
R=0.567\end{array}$ & NR \\
\hline & \begin{tabular}{|l} 
(Bezy et al., \\
2020c) \\
\end{tabular} & MVC & $\begin{array}{c}\text { HV \& different } \\
\text { cardiomyopathies }\end{array}$ & $R=0.31$ & & $\begin{array}{l}\text { LAVI: } \\
R=0.38\end{array}$ & $\begin{array}{c}\text { E/e': } \\
R=0.50\end{array}$ & $\begin{array}{c}\text { Study group: } \\
R=0.54\end{array}$ \\
\hline \multirow{2}{*}{ 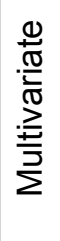 } & $\begin{array}{l}\text { (Cvijic et al., } \\
2020): \\
R=0.857^{*}\end{array}$ & MVC & HV \& arterial HT & $\beta=0.015$ & & $\begin{array}{l}\text { LA ø: } \\
\beta=1.353\end{array}$ & NR & $\begin{array}{l}\text { Study group: } \\
\qquad \beta=0.932\end{array}$ \\
\hline & $\begin{array}{l}\text { (Bezy et al., } \\
\text { 2020c): } \\
R=0.74^{*}\end{array}$ & MVC & $\begin{array}{c}\text { HV \& different } \\
\text { cardiomyopathies }\end{array}$ & & & $\begin{array}{l}\text { LAVI: } \\
\beta=0.20\end{array}$ & $\begin{array}{c}\text { E/e': } \\
\beta=0.19\end{array}$ & $\begin{array}{l}\text { Study group: } \\
\qquad \beta=0.24\end{array}$ \\
\hline
\end{tabular}

${ }^{*}$ Converted $\mathrm{R}^{2}$ to $\mathrm{R}$.

A summary of the reported wave speeds in literature together with aforementioned study parameters can be found in Table 4. Other relevant factors for shear wave speed interpretation are the used echocardiographic view and system (Palmeri et al., 2021). The manner of describing tissue motion (velocity/acceleration) is also mentioned in this table, as this affects the wave's frequency content and consequently the wave speed through dispersive effects (Trutna et al., 2020). Table 4 shows higher speeds for waves after MVC and AVC than for ARF-induced waves at end-diastole. However, it is difficult to interpret the absolute speed values of both techniques since their timing and wave nature might be different (see Figure 9). Wave speeds in patients were in general higher than those in healthy volunteers. 
Table 4 - Overview of reported shear wave speed values in healthy volunteer and patient studies with $n \geq 10$. For SWE based on intrinsic motion, speeds at MVC are tabulated as diastolic speeds and speeds at AVC are denoted as systolic speeds (abbreviations are as listed in Table 1, 2 and 3). In the column 'motion', 'a' means tissue acceleration and ' $v$ ' means tissue (Doppler) velocity are used for wave speed estimation.

\begin{tabular}{|c|c|c|c|c|c|c|c|c|c|c|c|c|c|c|}
\hline & \multirow[b]{2}{*}{ Study (ref \#) } & \multicolumn{6}{|c|}{ Population } & \multirow[b]{2}{*}{ System } & \multirow[b]{2}{*}{ Motion } & \multirow[b]{2}{*}{ Region } & \multirow[b]{2}{*}{ View } & \multicolumn{2}{|c|}{ Wave speeds } \\
\hline & & & $\mathbf{n}$ & $\begin{array}{l}\text { Age } \\
\text { [yrs] }\end{array}$ & $\begin{array}{c}\text { ED wall } \\
\text { thickness } \\
{[\mathrm{mm}]}\end{array}$ & $\begin{array}{c}\text { LAVI } \\
{\left[\mathrm{ml} / \mathrm{m}^{2}\right]}\end{array}$ & $\begin{array}{l}\mathrm{LA} \varnothing \\
{[\mathrm{mm}]}\end{array}$ & $\begin{array}{c}\text { E/e' } \\
{[-]}\end{array}$ & & & & & $\begin{array}{l}\text { Diastole } \\
{[\mathrm{m} / \mathrm{s}]}\end{array}$ & $\begin{array}{c}\text { Systole } \\
{[\mathrm{m} / \mathrm{s}]}\end{array}$ \\
\hline \multirow{10}{*}{ 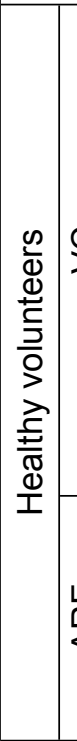 } & \multirow{7}{*}{ 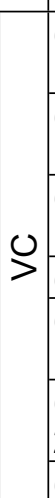 } & (Brekke et al., 2014) & 10 & NR & NR & NR & NR & NR & $\begin{array}{c}\text { GE } \\
\text { Vingmed }\end{array}$ & a & IVS & AP4C & NR & $5.41 \pm 1.28$ \\
\hline & & (Keijzer et al., 2020b) & 10 & $29.8 \pm 6.2$ & NR & & $\overline{N R}$ & NR & Zonare & $\mathrm{v}$ & IVS & $\begin{array}{l}\text { PLAX/ } \\
\text { AP4C }\end{array}$ & NR & $\begin{array}{l}\text { PLAX: } 3.7 \pm 0.4 \\
\text { AP4C: } 5.7 \pm 1.8\end{array}$ \\
\hline & & (Keijzer et al., 2019) & 10 & $29.8 \pm 6.2$ & NR & NR & NR & NR & \begin{tabular}{|c|} 
Zonare/ \\
Philips iE33 \\
\end{tabular} & v & IVS & PLAX & Zonare: $3.4 \pm 1.0$ & $\begin{array}{c}\text { Zonare: } 3.8 \pm 0.4 \\
\text { Philips iE33: } 3.2 \pm 0.9\end{array}$ \\
\hline & & (Petrescu et al., 2019) & 50 & 37.3 & 10.0 & 26.0 & NR & 6.3 & HD-pulse & $\mathrm{a}$ & IVS & PLAX & $3.54 \pm 0.93$ & $3.75 \pm 0.76$ \\
\hline & & (Santos et al., 2018) & 30 & $30.9 \pm 5.1$ & $9.1 \pm 1.4$ & $N R$ & NR & NR & HD-pulse & a & IVS & PLAX & $3.2 \pm 0.6$ & $3.5 \pm 0.6$ \\
\hline & & $\begin{array}{l}\text { (Strachinaru et al., } \\
\text { 2019a) }\end{array}$ & 20 & $45 \pm 13$ & & NR & & $8 \pm 1$ & $\begin{array}{l}\text { Phillips } \\
\text { iE33 }\end{array}$ & $\mathrm{v}$ & IVS & PLAX & $4.65 \pm 0.77$ & $3.61 \pm 0.46$ \\
\hline & & (Cvijic et al., 2020) & 26 & $55 \pm 15$ & $10 \pm 1$ & $31 \pm 6$ & $33 \pm 4$ & $6.8 \pm 1.5$ & HD-pulse & $a$ & IVS & PLAX & $4.04 \pm 0.96$ & NR \\
\hline & \multirow{3}{*}{$\frac{u}{\frac{w}{\alpha}}$} & (Song et al., 2016) & 10 & & $11.3 \pm 1.26$ & NR & NR & NR & Verasonics & $\mathrm{v}$ & IVS & $\begin{array}{l}\text { PLAX/ } \\
\text { PSAX }\end{array}$ & $\begin{array}{l}\text { PLAX: } 1.45 \pm 0.14 \\
\text { PSAX: } 1.81 \pm 0.19\end{array}$ & NR \\
\hline & & & & & & & & & & & \begin{tabular}{|c}
$\mathrm{LV}$ \\
anterior
\end{tabular} & $\begin{array}{l}\text { PLAX/ } \\
\text { PSAX }\end{array}$ & $\begin{array}{l}\text { PLAX: } 1.77 \pm 0.28 \\
\text { PSAX: } 1.96 \pm 0.38\end{array}$ & NR \\
\hline & & $\begin{array}{l}\text { (Villemain et al., } \\
2018)\end{array}$ & 60 & $\begin{array}{c}50.6 \pm 16 \\
9\end{array}$ & $5.9 \pm 1.4$ & $25.9 \pm 8.7$ & NR & $5.9 \pm 2.4$ & Aixplorer & $\mathrm{v}$ & IVS & $\begin{array}{l}\text { PLAX/ } \\
\text { PSAX }\end{array}$ & $\begin{array}{l}\text { PLAX: } 1.54 \pm 0.26 \\
\text { PSAX: } 2.16 \pm 0.42\end{array}$ & NR \\
\hline \multirow{5}{*}{ 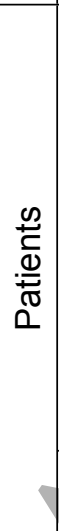 } & \multirow{4}{*}{9} & $\begin{array}{l}\text { Amyloidosis (Petrescu } \\
\text { et al., 2019) }\end{array}$ & 18 & 68.0 & 16.0 & 37.6 & NR & 18.0 & HD-pulse & a & IVS & PLAX & $6.33 \pm 1.63$ & $5.63 \pm 1.13$ \\
\hline & & $\begin{array}{l}\text { HCM (Strachinaru et } \\
\text { al., 2019a) }\end{array}$ & 20 & $48 \pm 13$ & $17 \pm 5$ & NR & NR & $17 \pm 9$ & $\begin{array}{l}\text { Phillips } \\
\text { iE33 }\end{array}$ & $\mathrm{v}$ & IVS & PLAX & $6.88 \pm 1.22$ & $5.13 \pm 0.68$ \\
\hline & & $\begin{array}{l}\text { Arterial HT with } \\
\text { hypertropic LV } \\
\text { remodeling (Cvijic et } \\
\text { al., 2020) } \\
\end{array}$ & 33 & $59 \pm 14$ & $14 \pm 2$ & $38 \pm 10$ & $40 \pm 7$ & $8.8 \pm 2.7$ & HD-pulse & a & IVS & PLAX & $5.83 \pm 1.20$ & NR \\
\hline & & $\begin{array}{l}\text { Heart transplantation } \\
\text { (Petrescu et al., } \\
2020) \text { : }\end{array}$ & 42 & $54 \pm 17.8$ & $13.3 \pm 3.1$ & 50.2 & NR & $8.3 \pm 3.1$ & HD-pulse & a & IVS & PLAX & $5.00 \pm 2.04$ & NR \\
\hline & \begin{tabular}{|l|}
$\frac{u}{\alpha}$ \\
$\frac{\alpha}{\alpha}$ \\
\end{tabular} & $\begin{array}{l}\text { HCM: (Villemain et } \\
\text { al., 2018) }\end{array}$ & 20 & $57 \pm 17.5$ & $20.8 \pm 5.1$ & $43.4 \pm 18.9$ & NR & $16.1 \pm 6.5$ & Aixplorer & $\mathrm{v}$ & IVS & PSAX & $3.56 \pm 1.71^{*}$ & NR \\
\hline
\end{tabular}

${ }^{*}$ Converted from stiffness to shear wave speed by using equation (1) and assuming a $\rho$ of $1000 \mathrm{~kg} / \mathrm{m}^{3}$ 
Feasibility, reproducibility and availability

For ARF-based SWE, Song et al. (Song et al., 2016) reported good success rates $(>66.7 \%)$ for four out of seven studied echocardiographic views at end-diastole $(n=10)$ : LV posterior free wall in PSAX; basal IVS in PSAX; mid-IVS in PSAX and basal IVS in PLAX. Furthermore, the first two views showed the highest repeatability across three different days. Villemain et al. (Villemain et al., 2018) reported a $100 \%$ success rate when studying ARF-induced shear waves in the IVS in PLAX and PSAX ( $n=80)$ - after excluding subjects based on predefined criteria (echogenicity and presence of scar due to earlier infarct). Additionally, the authors in (Villemain et al., 2018) found no statistical difference between measurements at baseline and after three months $(n=15)$. Even though the feasibility of ARF-based SWE throughout the cardiac cycle is not yet studied in the clinics, a previous preclinical study (Keijzer et al., 2020a) reported a success rate of $32 \%$ for 65 ARF-based SWE acquisitions ( $n=4)$. This demonstrates the SNR challenges for in vivo ARFbased SWE.

The reproducibility of natural SWE measurements in the heart has been more extensively studied. Studies report in general a high success rate (e.g. $94 \%$ for AVC and $84 \%$ for MVC for $n=63$ (Petrescu et al., 2019)), when excluding subjects with cardiac arrhythmias, histological or clinical evidence of allograft rejection, significant LCA stenosis, more than moderate valvular disease and poor echogenicity. Healthy volunteer studies (Santos et al., 2018; Keijzer et al., 2019) reported a moderate reproducibility: variabilities up to $1 \mathrm{~m} / \mathrm{s}$ were observed, mainly due to measurement inaccuracies such as a limited SNR and shear wave tracking length. Keijzer et al. (Keijzer et al., 2019) suggested to improve measurement precision by averaging wave speeds over 10 heartbeats and multiple M-mode line analyses per recording.

Most of the presented work in this review has been performed with research systems or clinical systems that have been adapted for research purposes. For ARF-based SWE, several commercial elastography functions are available from different vendors (e.g. Shear Wave Elastography from SuperSonic Imagine, Virtual Touch ${ }^{\mathrm{TM}}$ quantification from Philips/Siemens (Sigrist et al., 2017; Barr et al., 2015)), but these are primarily used for liver and breast tissue and are not optimized yet for cardiac applications. For natural SWE, tissue Doppler imaging (TDI) applications on current clinical scanners can be used. Indeed, Pislaru et al. (Pislaru et al., 2017) reported a frame rate of $350-460 \mathrm{~Hz}$ on the GE Vivid E9 and Philips iE33 scanner. This can even be elevated to $400-700 \mathrm{~Hz}$ on the Philips iE33 system (Strachinaru et al., 2017). Recently, Canon Medical Systems provides Shear Wave Dispersion Imaging for determining tissue's viscoelastic properties in case of fibrotic liver disease (Sugimoto et al., 2020). It can be expected that with time, high-end commercial systems and corresponding software can be made ready for cardiac SWE - natural as well as ARF-based - while evidence of the additional clinical information is building up.

\section{Future perspectives}

Best practices in cardiac shear wave elastography 
As the number of clinical studies on cardiac SWE is growing, the need for consistent data collection and reporting is urgent, and we formulate some recommendations that may improve SWE accuracy and facilitate comparison of SWE results between studies. With the currently available 2D SWE technology, shear waves are typically tracked in the IVS which is located not too deep nor too shallow for shear wave generation/tracking. The echocardiographic views are limited to PLAX or PSAX for ARF-based SWE, because a quasi-orthogonal relationship between ultrasound beam and cardiac wall is required for inducing transversal wave motion. On the other hand, for natural shear waves, PLAX or AP4C view can be used. It should however be noted that each view tracks a different component of tissue motion and thus potentially a different wave mode (Keijzer et al., 2020b). Depending on the technological advancements, more echocardiographic views/regions might be possible in the near future.

A variety of SWE-metrics have been reported in literature (illustrated in Table 3 and Table 4). We strongly discourage reporting a shear or Young's modulus through the use of equations (1) and/or (3), since this is associated with stringent assumptions concerning mechanical properties which do not hold for the myocardium (i.e. linear elasticity, isotropy and bulk size). Figure 10 summarizes our recommendations for data reporting in cardiac SWE in clinical practice. Ideally, future research should clearly report the propagation speed of the traveling wave in the time domain together with the main excited frequency. As it is unclear up to now what type of tissue motion (velocity/acceleration) should best be used to determine wave speed, we suggest to report propagation speeds based on both tissue velocity and acceleration to enable comparison between future studies. Furthermore, it is recommended to also report (Figure 10): (i) systemdependent factors which have a non-negligible effect on SWE results but are inherent to the available SWE modality, (ii) technical settings on which operators do have their say and (iii) population characteristics describing mechanical and biological variations. Concerning technical settings, next to echocardiographic view and cardiac region as discussed before, the M-line for wave speed estimation should be positioned in the middle of the cardiac wall parallel to the border (i.e. along the assumed propagation direction). We suggest to repeat this M-line measurement multiple times for multiple SWE acquisitions and to report the median speed together with its interquartile range (Santos et al., 2018; Keijzer et al., 2019). A more advanced material characterization can be obtained from SWE by studying the wave's frequency behavior (dispersion) or multiple echocardiographic views (anisotropy). However, we note that advanced material characterization can be challenging and is often associated with more variable results in low SNR data which can increase the complexity of inter-study comparisons; as such, we recommend including the group SWS measurements as well in these studies. If the resolution of the imaging system is high enough, transmural wave speed variations can also be studied to investigate the myocardial anisotropy, especially in PSAX (see Figure 8). As the wave propagation direction is unknown for natural SWE, 3D imaging will offer additional insights for advancing material characterization. 

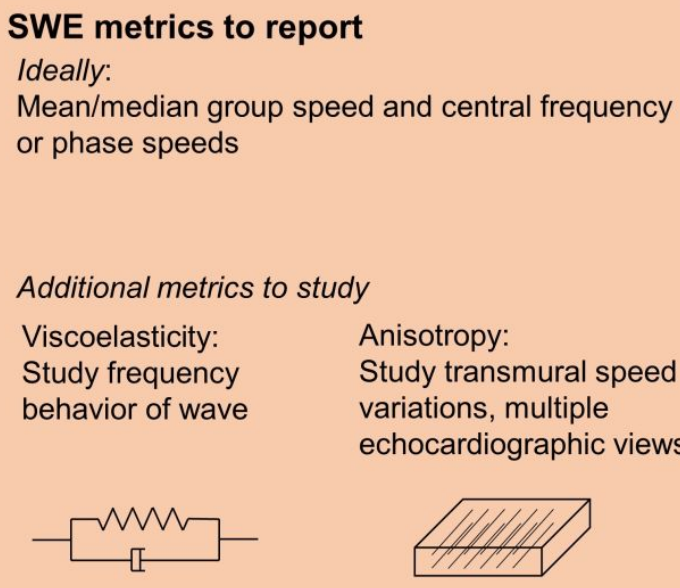

\section{Additional metrics to report}

System-dependent factors

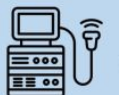

Scanner

Acquisition settings

Manner of describing tissue motion

Post-processing algorithm

Technical settings

Echocardiographic view

Cardiac region

M-line position

Number of measurements (SWE \& M-line)

Population characteristics

Measures of cardiac geometry: wall thickness, radius Measures of hemodynamics: E/e', pressure, LA size Information on when exactly the SWE measurements were made in the cardiac cycle (e.g. ECG)

Age

Figure 10 - Recommendations for standardized data reporting based on the currently available SWE technology in the clinics.

\section{Technical and mechanical challenges to overcome}

Even though multiple clinical studies have successfully reported results of transthoracic SWE, the technique still faces many challenges of both a technical and mechanical nature. Indeed, the feasibility of transthoracic ARF-based SWE - especially in systole - is generally lower than for natural SWE due to difficulties to transmit a sufficient amount of energy into the cardiac wall for shear wave excitation and to consequently track the generated wave in an acoustically safe manner. This is partly due to location of the heart which is encased by ribs and surrounded by lung tissue limiting the acoustic accessibility. An external vibrator might overcome the limitations of penetration depth, but is associated with other issues such as shear wave speed estimation biases due to misalignment of the measurement plane and the excitation source but also coupling uncertainties of the vibration energy into the myocardium. The magnitude of particle motion for natural SWE is in general higher than for ARF-based SWE (tens of $\mathrm{mm} / \mathrm{s}$ instead of a few $\mathrm{mm} / \mathrm{s}$ in Figure 9), however the wave speed might be less accurately tracked because of a larger spatial wavelength (a few cm vs. a few $\mathrm{mm}$ in Figure 9) within the limited field-of-view $(3-4 \mathrm{~cm}$ ). Additionally, the technical settings of the used elastography mode on the ultrasound scanner (e.g. temporal and spatial characteristics of the ARF, tissue motion estimation algorithm, shear wave speed estimation algorithm, etc.) will also affect the resulting wave speed. A clear communication of the device manufacturer to the sonographers and physicians is necessary to better understand what the system is reporting. We have formulated some guidelines on standardization of SWE data collection and reporting, but it is clear that a dedicated committee endorsed by the leading echography/cardiology societies needs to set these criteria as has been done for the staging of liver fibrosis (Quantitative Imaging Biomarker Alliance by the Radiological Society of North America (Palmeri et al., 2021)) and cardiac speckle tracking echocardiography (Voigt et al., 2015).

This paper focused on mechanical factors interfering with cardiac SWE. However, the sensitivity of the SWE technique to each considered mechanical factor remains unclear: is SWE more 
sensitive to changes in myocardial mechanical properties than to, for example, changes in hemodynamics? And is this different for ARF-based and natural SWE? Furthermore, the arrival of 3D SWE might further improve our understanding of both types of SWE, especially for natural SWE as the spatial and temporal characteristics of the wave excitation source are unknown. It should also be noted that shear wave measurements provide only a local measurement of stiffness, assessed within the size of the field of view, and it should be further investigated how this relates to global stiffness changes, as reflected by an altered end-diastolic pressure-volume relationship.

\section{Conclusion}

Ultrasound-based SWE has a tremendous potential for non-invasive characterization of the active and passive stiffness of the heart. The number of clinical studies demonstrating the discriminative power of shear wave speed for cardiac pathology is growing. However, one should be aware that mechanical factors, next to pathology, affect wave speed estimation. With this paper, we aim to contribute to a better conceptual understanding of shear wave physics and, consequently, a deeper insight for a correct interpretation of findings.

\section{Acknowledgements}

This work was supported by the Research Foundation Flanders (FWO, Brussels, Belgium) under grant $1211620 \mathrm{~N}$ to Annette Caenen.

Kathryn R. Nightingale has intellectual property related to radiation force-based imaging technologies that has been licensed to Siemens, Samsung and MicroElastic Ultrasound Systems. The other authors declare that they have no conflict of interest. 


\section{Appendix A: Lamb waves in cardiac SWE}

The cardiac wall is typically approximated as a fluid-loaded (visco)elastic plate, for which the Lamb wave theory is manipulated to better understand the geometrical (and viscoelastic) effect on cardiac shear wave propagation (Nguyen et al., 2011; Nenadic et al., 2011; Pislaru et al., 2014b; Urban et al., 2013; Kanai, 2005; Keijzer et al., 2020b). When viscoelasticity is included, a Voigt model is commonly used to describe the rheological behavior. This material model assumes a viscous component represented by a dashpot (with viscosity $\eta$ ) in parallel with the elastic component (spring with spring constant $\mu$ ). To better understand the effect of geometry and viscoelasticity on wave propagation, we plotted the theoretical phase speed characteristics of Lamb waves for a representative elastic and viscoelastic myocardial model in diastole and systole in Figure A11a, in comparison to that of a bulk medium with the same material parameters. The effect of geometry can be derived by comparing the phase speed characteristics of a bulk medium to that of the plates for an elastic material: the phase speed is independent of frequency for bulk media $(1.3 \mathrm{~m} / \mathrm{s}$ in diastole and $4.8 \mathrm{~m} / \mathrm{s}$ in systole); whereas the phase speeds in plates increase as a function of frequency until they reach a plateau-value (i.e. the plate wave speed, which is about $95 \%$ of the bulk shear wave speed (Rose, 2014)). The effect of viscoelasticity is also demonstrated in Figure A11a, and shows for phase speed an increasing trend as a function of frequency independent of the considered geometry. It should be noted that geometry, viscoelasticity or a combination of the two can result in wave dispersion, but is dependent on the excitation properties (e.g. bandwidth, central frequency) if dispersion is observed. For example, when considering a traveling mechanical wave with a frequency content between $200-400 \mathrm{~Hz}$, Figure A11a shows a frequency-dependent wave speed in systole for an elastic plate of $10 \mathrm{~mm}$, but not for an elastic plate of $15 \mathrm{~mm}$. Figure A11a also demonstrates that low frequency excitations such as natural waves after valve clósure are more sensitive to thickness variations: the phase speed can increase $24 \%$ (peak frequency of $40 \mathrm{~Hz}$ for MVC (Vos et al., 2017)) in diastole and $40 \%$ in systole (peak frequency of $80 \mathrm{~Hz}$ for AVC (Vos et al., 2017)) when myocardial thickness changes from 10 to $15 \mathrm{~mm}$.

Some cardiac SWE studies (Kanai, 2005; Urban et al., 2013; Nenadic et al., 2018; Pislaru et al., 2014b) have set one step further in post-processing the SWE results by reporting elasticity and viscosity values using the Lamb wave model, as summarized in Table A5. The process to estimate elasticity and viscosity values is as follows. First, the frequency-dependent behavior of the studied mechanical wave is investigated by (i) performing multiple wave speed measurements while varying the frequency of the mechanical actuator (Pislaru et al., 2014b; Urban et al., 2013) or by (ii) applying a fast Fourier transform (FFT) on the temporal wave data to analyze the frequency content of the mechanical wave (Deffieux et al., 2009; Couade et al., 2010). Both cases will give the phase speed characteristics as a function of frequency, of which examples are shown for two types of shear wave excitation in Figure A11b. Second, elasticity and viscosity values are obtained by fitting the theoretical Lamb wave model to the measured phase speed characteristics. LV phantom studies (Caenen et al., 2017; Sabbadini et al., 2021) have shown that the elasticity results based on the phase speed will better approach the true stiffness than those based on the group speed (deviations up to $+12 \%$ vs. $-67 \%$ ). However, it should be noted that this Lamb wave fitting comes with several assumptions such as plate geometry, smooth walls, and isotropy which 
a.

Theory
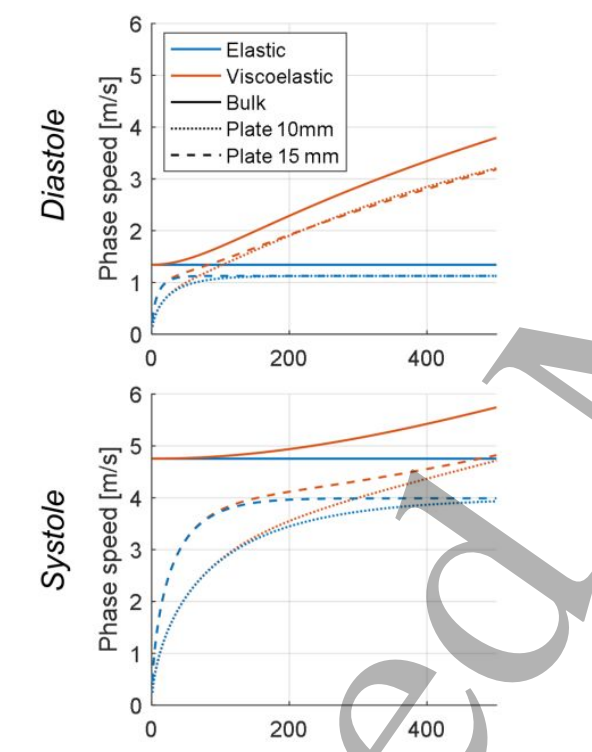

b.

\section{b. Measurement}

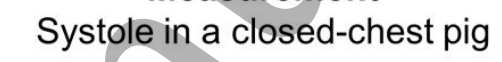

do not hold for the cardiac wall. Furthermore, frequency analyses in in vivo cardiac SWE are sparsely reported in literature (Vos et al., 2017; Kanai, 2005) because of the non-suitability of mechanical actuators in vivo (resulting in a broadband excitation) and the low resolution in combination with low SNR for an accurate FFT. Furthermore, frequency analysis on natural waves do not allow to get a complete picture of the frequency behavior of the tissue of interest because All reported elasticity and viscosity values in Table A5 are in the same range, except for the systolic elasticity and viscosity reported by Kanai et al. (Kanai, 2005) ( $\mu_{1}=30 \mathrm{kPa}$ and $\mu_{2}$ $=70-400 \mathrm{~Pa} \cdot \mathrm{s}$ ), which is larger than the elasticity and viscosity reported by the other studies in Table A5. This might be due to a difference in investigated region (septum vs. free wall), a different view showing different wave types (Keijzer et al., 2020b) or a variable accuracy in the Lamb wave analysis when the frequency of the wave excitation alters.
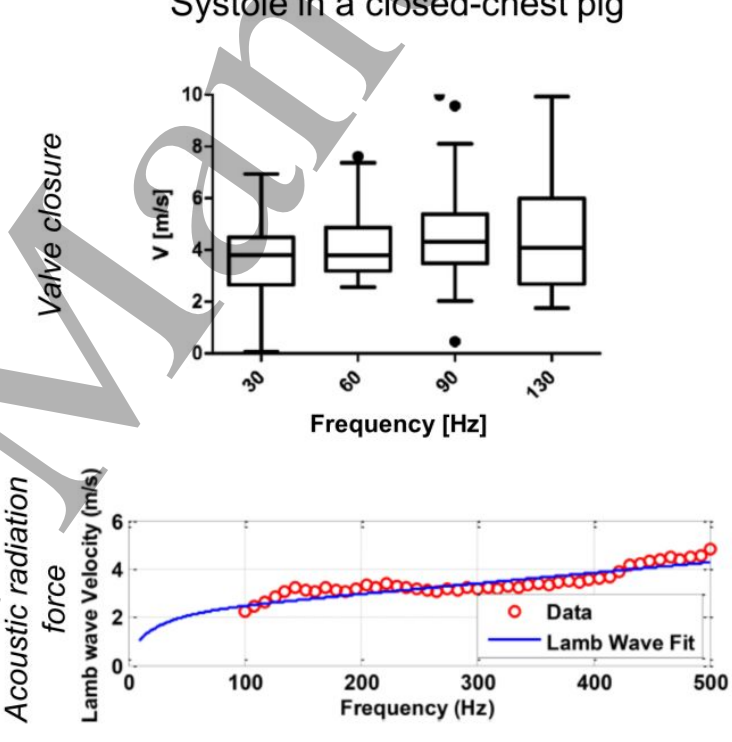

Figure A11 - Effect of geometry and viscoelasticity on shear wave properties. (a) Theoretical predictions of the phase speed variations in a bulk medium and plate (with a thickness of $10 \mathrm{~mm}$ and $15 \mathrm{~mm}$ ), when assuming an elastic and viscoelastic medium (Voigt model). The material parameters are $\mu=1.8 \mathrm{kPa}$ (and $\eta=2.7 \mathrm{~Pa} \cdot \mathrm{s}$ ) in diastole; and $\mu=22.6 \mathrm{kPa}$ (and $\eta=5.9 \mathrm{~Pa} \cdot \mathrm{s}$ ) in systole - as reported by Pislaru et al. (Pislaru et al., 2014b). Note that the phase speed characteristics of one mode (antisymmetric zero order mode) - expected dominant mode in cardiac SWE - are shown for a fluid-loaded plate. (b) Measured shear wave spectra in a closed-chest pig in systole: group velocities after aortic valve closure (Vos et al., 2017) (upper panel) and phase velocities in systole after acoustic radiation force application (Nenadic et al., 2018) (lower panel). Adapted with permission from Vos et al. (Vos et al., 2017) and Nenadic et al. (Nenadic et al., 2018).

Table A5 - Reported viscoelastic properties in cardiac SWE when assuming a plate-like myocardium with its viscoelastic material properties obeying a Voigt model. Diastolic values in natural SWE corresponds to wave analysis after mitral valve closure; whereas systolic values are obtained for wave analysis after aortic valve closure. (VC: valve closure, MS: mechanical stimulation, ARF: acoustic radiation force, IVS: interventricular septum, LVFW: left ventricular free wall, NR: not reported)

\begin{tabular}{|l|l|l|l|l|l|}
\hline Study & Excit & Region & Species & Diastole & Systole \\
\hline
\end{tabular}




\begin{tabular}{|c|c|c|c|c|c|c|c|}
\hline (ref \#) & ation & & & $\begin{array}{c}\text { Elasticity } \mu \\
{[\mathrm{kPa}]}\end{array}$ & $\begin{array}{c}\text { Viscosity } n \\
{[\mathrm{~Pa} \cdot \mathrm{s}]}\end{array}$ & $\begin{array}{c}\text { Elasticity } \mu \\
{[\mathrm{kPa}]}\end{array}$ & $\begin{array}{c}\text { Viscosity } \mathbf{n} \\
\text { [Pa-s] }\end{array}$ \\
\hline \begin{tabular}{|l} 
Kanai, \\
2005)
\end{tabular} & VC & IVS & $\begin{array}{l}\text { Human } \\
(n=5)\end{array}$ & NR & NR & $30 \mathrm{kPa}$ & 70-400 Pa.s \\
\hline \begin{tabular}{|l|} 
(Urban et \\
al., 2013) \\
\end{tabular} & MS & LVFW & $\begin{array}{c}\text { Open-chest } \\
\text { pig }(n=8)\end{array}$ & $1.81 \pm 0.8 \mathrm{kPa}$ & $2.7 \pm 0.56 \mathrm{~Pa} \cdot \mathrm{s}$ & 21.1 & $4.16 \pm 4.32$ \\
\hline \begin{tabular}{|l|} 
(Pislaru \\
et al., \\
$2014 \mathrm{~b})$
\end{tabular} & MS & LVFW & $\begin{array}{l}\text { Open-chest } \\
\text { pig }(n=10)\end{array}$ & $1.8 \pm 0.8 \mathrm{kPa}$ & 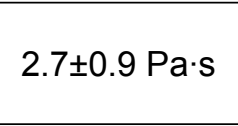 & $2 . .6$ & $5.9 \pm 4.7 \mathrm{~Pa} \cdot \mathrm{s}$ \\
\hline $\begin{array}{l}\text { (Nenadic } \\
\text { et al., } \\
2018) \\
\end{array}$ & ARF & LVFW & $\begin{array}{c}\text { Open-chest } \\
\text { pig }(n=1)\end{array}$ & $2.24 \pm 0.54 \mathrm{kPa}$ & $3.36 \pm 0.5 \mathrm{~Pa} \cdot \mathrm{s}$ & 12.4 & $3.99 \pm 1.19 \mathrm{~Pa} \cdot \mathrm{s}$ \\
\hline \begin{tabular}{|l} 
(Nenadic \\
et al., \\
$2018)$
\end{tabular} & ARF & LVFW & Pig $(n=1)$ & $5.1 \mathrm{kPa}$ & 3.2 Pa.s & a & 6.8 Pa.s \\
\hline
\end{tabular}




\section{References}

Barr R G, Nakashima K, Amy D, Cosgrove D, Farrokh A, Schafer F, Bamber J C, Castera L, Choi B I, Chou Y $H$, Dietrich C F, Ding H, Ferraioli G, Filice C, Friedrich-Rust M, Hall T J, Nightingale K R, Palmeri M L, Shiina T, Suzuki S, Sporea I, Wilson S and Kudo M 2015 WFUMB guidelines and recommendations for clinical use of ultrasound elastography: Part 2: breast U/trasound Med Biol 41 1148-60

Bercoff J, Tanter M, Muller M and Fink M 2004 The Role of Viscosity in the Impulse Diffraction Field of Elastic Waves Induced by the Acoustic Radiation Force IEEE Trans Ultrason Ferroelectr Freq Control 51 1523-36

Bezy S, Cvijic M, Petrescu A, Orlowska M, Santos P, Duchenne J, Chakraborty B, Pedrosa J, D'Hooge J and Voigt J U 2020a Shear wave propagation velocity after aortic valve closure could be a novel parameter for myocardial contractility European Heart Journal - Cardiovascular Imaging $\mathbf{2 1}$

Bezy S, Duchenne J, Orlowska M, Wouters L, Caenen A, Keijzer L B H, Cvijic M, D'Hooge J and Voigt J U $2020 \mathrm{~b}$ The behaviour of natural shear waves under different loading conditions European Heart Journal 41

Bezy S, Petrescu A, Cvijic M, Orlowska M, Santos P, Werner A E, Duchenne J, Voigt J U and D'Hooge J 2020c Determinants of the propagation velocity of natural shear waves in cardiac shear wave elastography. In: IEEE International Ultrasound Symposium, (Las Vegas, NV, USA

Bouchard R, Hsu D, Wolf P and Trahey G 2009 In Vjvo Cardiac Acoustic-Radiation-Force-Driven Shear Wave Velocimetry Ultrason Imaging 31 201-13

Brekke B, Nilsen L C, Lund J, Torp H, Bjastad T, Amundsen B H, Stoylen A and Aase S A 2014 Ultra-high frame rate tissue Doppler imaging Ultrasound in medicine \& biology 40 222-31

Caenen A, Pernot M, Peirlinck M, Mertens L, Swillens A and Segers P 2018 An in silico framework to analyze the anisotropic shear wave mechanics in cardiac shear wave elastography Physics in medicine and biology 63

Caenen A, Pernot M, Shcherbakova D A, Mertens L, Kersemans M, Segers P and Swillens A 2017 Investigating Shear Wave Physics in a Generic Pediatric Left Ventricular Model via In Vitro Experiments and Finite Element Simulations IEEE Trans Ultrason Ferroelectr Freq Control 64349 61

Catheline S and Benech N 2015 Longitudinal shear wave and transverse dilatational wave in solids J Acoust Soc Am 137 200-5

Catheline S, Wu F and Fink M 1999 A solution to diffraction biases in sonoelasticity: The acoustic impulse technique J Acoust Soc Am 105 2941-50

Cobbold R S C 2002 Foundations of Biomedical Ultrasound: Oxford University Press)

Couade M, Pernot M, Messas E, Bel A, Ba M, Hagege A, Fink M and Tanter M 2011 In vivo quantitative mapping of myocardial stiffening and transmural anisotropy during the cardiac cycle IEEE Trans Med Imaging 30 295-305

Couade M, Pernot M, Prada C, Messas E, Emmerich J, Bruneval P, Criton A, Fink M and Tanter M 2010 Quantitative assessment of arterial wall biomechanical properties using shear wave imaging Ultrasound Med Biol 36 1662-76

Cvijic M, Bezy S, Petrescu A, Santos P, Orlowska M, Chakraborty B, Duchenne J, Pedrosa J, Vanassche T, D'Hooge J and Voigt J U 2020 Interplay of cardiac remodelling and myocardial stiffness in hypertensive heart disease: a shear wave imaging study using high-frame rate echocardiography Eur Heart J Cardiovasc Imaging 21 664-72

Deffieux T, Montaldo G, Tanter M and Fink M 2009 Shear wave spectroscopy for in vivo quantification of human soft tissues visco-elasticity IEEE Trans Med Imaging 28 313-22 
Deng Y, Rouze N C, Palmeri M L and Nightingale K R 2017 Ultrasonic Shear Wave Elasticity Imaging (SWEI) Sequencing and Data Processing Using a Verasonics Research Scanner IEEE Trans Ultrason Ferroelectr Freq Control 1-

Elgeti T, Knebel F, Hättasch R, Hamm B, Braun J and Sack I 2014 Shear-wave amplitudes measured with cardiac MR elastography for diagnosis of diastolic dysfunction Radiology 271 681-7

Elgeti T and Sack I 2014 Magnetic Resonance Elastography of the Heart Current Cardiovascular Imaging Reports 7

Ferraioli G, Filice C, Castera L, Choi B I, Sporea I, Wilson S R, Cosgrove D, Dietrich CF, Amy D, Bamber J C, Barr R, Chou Y H, Ding H, Farrokh A, Friedrich-Rust M, Hall T J, Nakashima K, Nightingale K R, Palmeri M L, Schafer F, Shiina T, Suzuki S and Kudo M 2015 WFUMB guidelines and recommendations for clinical use of ultrasound elastography: Part 3: liver Ultrasound Med Biol 41 1161-79

Fung Y C 1993 Biomechanics - Mechanical Properties of Living Tissues

Gao L, Parker K J, Lerner R M and Levinson S F 1996 Imaging of the elastic properties of tissue - A review Ultrasound Med Biol 22 959-77

Greenleaf J F, Fatemi M and Insana M 2003 Selected methods for imaging elastic properties of biological tissues Annu Rev Biomed Eng 5 57-78

Guimarães C F, Gasperini L, Marques A P and Reis R L 2020 The stiffness of living tissues and its implications for tissue engineering Nature Reviews Materials 5 351-70

Hollender P, Bradway D, Wolf P, Goswami R and Trahey G 2013 Intracardiac acoustic radiation force impulse (ARFI) and shear wave imaging in pigs with focal infarctions IEEE Trans Ultrason Ferroelectr Freq Control 60 1669-82

Hollender P J, Wolf P D, Goswami R and Trahey G E 2012 Intracardiac echocardiography measurement of dynamic myocardial stiffness with shear wave velocimetry Ultrasound Med Biol 38 1271-83

Kanai H 2005 Propagation of spontaneously actuated pulsive vibration in human heart wall and in vivo viscoelasticity estimation. IEEE Trans Ultrason Ferroelectr Freq Control 52 1931-42

Kasai C, Namekawa K, Koyano A and Omoto R 1985 Real-Time Two-Dimensional Blood Flow Imaging Using an Autocorrelation Technique IEEE Trans Sonics Ultrasonics SU-32 458-64

Keijzer L B H, Bosch J G, Verweij M D, De Jong N and Vos H J IEEE International Ultrasound Symposium, (Washington DC, USA, 2018), vol. Series) pp 1-4

Keijzer L B H, Caenen A, Voorneveld J, Strachinaru M, Bowen D J, van de Wouw J, Sorop O, Merkus D, Duncker D J, van der Steen A F W, de Jong N, Bosch J G and Vos H J 2020a A direct comparison of natural and acoustic-radiation-force-induced cardiac mechanical waves Sci Rep 1018431

Keijzer L B H, Strachinaru M, Bowen D J, Caenen A, Van der Steen A F W, Verweij M D, De Jong N, Bosch J $G$ and Vos H J 2020b Parasternal versus Apical View in Cardiac Natural Mechanical Wave Speed Measurements IEEE Trans Ultrason Ferroelectr Freq Control 67 1590-602

Keijzer L B H, Strachinaru M, Bowen D J, Geleijnse M L, van der Steen A F W, Bosch J G, de Jong N and Vos H J 2019 Reproducibility of Natural Shear Wave Elastography Measurements Ultrasound Med Biol $453172-85$

Knight A E, Trutna C A, Rouze N C, Hobson-Webb L D, Caenen A, Jin F Q, Palmeri M L and Nightingale K R 2021 Full Characterization of in vivo Muscle as an Elastic, Incompressible, Transversely Isotropic Material ussing Ultrasonic Rotational 3D Shear Wave Elasticity Imaging IEEE Trans Med Imaging PP

Kwiecinski W, Bessiere F, Colas E C, N'Djin W A, Tanter M, Lafon C and Pernot M 2015 Cardiac shear-wave elastography using a transesophageal transducer: application to the mapping of thermal lesions in ultrasound transesophageal cardiac ablation Phys Med Biol 60 7829-46

Lee W N, Larrat B, Pernot M and Tanter M 2012a Ultrasound elastic tensor imaging: comparison with MR diffusion tensor imaging in the myocardium Phys Med Biol 57 5075-95 
Lee W N, Pernot M, Couade M, Messas E, Bruneval P, Bel A, Hagege A A, Fink M and Tanter M 2012b Mapping myocardial fiber orientation using echocardiography-based shear wave imaging IEEE Trans Med Imaging 31 554-62

Mariappan Y K, Glaser K J and Ehman R L 2010 Magnetic resonance elastography: a review Clin Anat 23 497-511

Montaldo G, Tanter M, Bercoff J, Benech N and Fink M 2009 Coherent Plane-Wave Compounding for Véry High Frame Rate Ultrasonography and Transient Elastography IEEE Trans Ultrason Ferroelectr Freq Control 56 489-506

Nenadic I Z, Urban M W, Mitchell S A and Greenleaf J F 2011 Lamb wave dispersion ultrasound vibrometry (LDUV) method for quantifying mechanical properties of viscoelastic solids Phys Med Biol 56 224564

Nenadic I Z, Urban M W, Pislaru C, Escobar D, Vasconcelos L and Greenleaf J F 2018 In Vivo Open- and Closed-chest Measurements of Left-Ventricular Myocardial Viscoelasticity using Lamb wave Dispersion Ultrasound Vibrometry (LDUV): A Feasibility Study Biomed Phys Eng Express 4

Nguyen T-M, Couade M, Bercoff J and Tanter M 2011 Assessment of Viscous and Elastic Properties of SubWavelength Layered Soft Tissues Using Shear Wave Spectroscopy: Theoretical Framework and In Vitro Experimental Validation IEEE Trans Ultrason Ferroelectr Freq Control 58 2305-15

Nightingale K R, Palmeri M L, Nightingale R W and Trahey G E 2001 On the feasibility of remote palpation using acoustic radiation force $J$ Acoust Soc Am 110 625-34

Nightingale K R, Rouze N C, Rosenzweig S J, Wang M H, Abdelmalek M F, Guy C D and Palmeri M L 2015 Derivation and analysis of viscoelastic properties in human liver: impact of frequency on fibrosis and steatosis staging IEEE Trans Ultrason Ferroelectr Freq Control 62 165-75

Olson T R and Pawlina W 2008 A.D.A.M. Student Atlas of Anatomy

Ophir J, Céspedes H, Ponnekanti H, Yazdi Y and Li X 1991 Elastography: A quantitative method for imaging the elasticity of biological tissues Ultrason Imaging 13 111-34

Palmeri M L, Milkowski A, Barr R, Carson P, Couade M, Chen J, Chen S, Dhyani M, Ehman R, Garra B, Gee A, Guenette G, Hah Z, Lynch T, Macdonald M, Managuli R, Miette V, Nightingale K R, Obuchowski N, Rouze N C, Morris D C, Fielding S, Deng Y, Chan D, Choudhury K, Yang S, Samir A E, Shamdasani V, Urban M, Wear K, Xie H, Ozturk A, Qiang B, Song P, McAleavey S, Rosenzweig S, Wang M, Okamura Y, McLaughlin G, Chen Y, Napolitano D, Carlson L, Erpelding T and Hall T J 2021 Radiological Society of North America/Quantitative Imaging Biomarker Alliance Shear Wave Speed Bias Quantification in Elastic and Viscoelastic Phantoms J Ultrasound Med 40 569-81

Papadacci C, Finel V, Villemain O, Tanter M and Pernot M 2020 4D Ultrafast Ultrasound Imaging of Naturally Occurring Shear Waves in the Human Heart IEEE Transactions on Medical Imaging 39 4436-44

Parker K J, Ormachea J and Hah Z 2018 Group versus Phase Velocity of Shear Waves in Soft Tissues Ultrason Imaging 40 343-56

Pernot M, Couade M, Mateo P, Crozatier B, Fischmeister R and Tanter M 2011 Real-time assessment of myocardial contractility using shear wave imaging J Am Coll Cardiol 58 65-72

Pernot M, Lee W-N, Bel A, Mateo P, Couade M, Tanter M, Crozatier B and Messas E 2016 Shear wave imaging of passive diastolic myocardial stiffness: stunned vs infarcted myocardium JACC Cardiovasc Imaging 9 1023-30

Pernot M and Villemain O 2019 In the Heart of Stiffness: Are Natural Heart Vibrations Reliable Enough to Assess Myocardial Stiffness, The New Holy Grail in Echocardiography? JACC Cardiovasc Imaging 12 2399-401

Petrescu A, Bezy S, Cvijic M, Santos P, Orlowska M, Duchenne J, Pedrosa J, Van Keer J M, Verbeken E, von Bardeleben S, Droogne W, Bogaert J, Van Cleemput J, D'Hooge J and Voigt J U 2020 Shear Wave 
Elastography Using High-Frame-Rate Imaging in the Follow-Up of Heart Transplantation Recipients JACC Cardiovasc Imaging 13 2304-13

Petrescu A, Santos P, Orlowska M, Pedrosa J, Bezy S, Chakraborty B, Cvijic M, Dobrovie M, Delforge M, D'Hooge J and Voigt J U 2019 Velocities of Naturally Occurring Myocardial Shear Waves Increase With Age and in Cardiac Amyloidosis JACC Cardiovasc Imaging 12 2389-98

Pislaru C, Alashry M M, Thaden J J, Pellikka P A, Enriquez-Sarano M and Pislaru S V 2017 Intrinsic Wáve Propagation of Myocardial Stretch, A New Tool to Evaluate Myocardial Stiffness: A Pilot Study in Patients with Aortic Stenosis and Mitral Regurgitation J Am Soc Echocardiogr 30 1070-80

Pislaru C, Pellikka P A and Pislaru S V 2014a Wave propagation of myocardial stretch: correlation with myocardial stiffness Basic research in cardiology 109438

Pislaru C, Urban M W, Pislaru S V, Kinnick R R and Greenleaf J F 2014b Viscoelastic properties of normal and infarcted myocardium measured by a multifrequency shear wave method: comparison with pressure-segment length method Ultrasound Med Biol 40 1785-95

Rose J L 2014 Ultrasonic guided waves in solid media (New York: Cambridge University Press)

Rouze N C, Wang M H, Palmeri M L and Nightingale K R 2013 Finite element modeling of impulsive excitation and shear wave propagation in an incompressible, transversely isotropic medium $J$ Biomech 46 2761-8

Sabbadini A, Caenen A, Keijzer L B H, van Neer P, Vos H J, de Jong N and Verweij M D 2021 Tapering of the interventricular septum can affect ultrasound shear wave elastography: An in vitro and in silico study J Acoust Soc Am 150428

Salles S, Espeland T, Molares A, Aase S A, Hammer T A, Støylen A, Aakhus S, Lovstakken L and Torp H 2020 3D Myocardial Mechanical Wave Measurements JACC: Cardiovascular Imaging

Salles S, Lovstakken L, Aase S A, Bjastad T G and Torp H 2019 Clutter Filter Wave Imaging IEEE Trans Ultrason Ferroelectr Freq Control 66 1444-52

Sandrin L, Catheline S, Tanter M, Hennequin X and Fink M 1999 Time-resolved pulsed elastography with ultrafast ultrasonic imaging Ultrason Imaging 21 259-72

Santos P, Petrescu A, Pedrosa J, Orlowska M, Komini V, Voigt J-U and D'hooge J 2018 Natural shear wave imaging in the human heart: normal values, feasibility and reproducibility IEEE Trans Ultrason Ferroelectr Freq Control 66 442-52

Sarvazyan A P, Rudenko O V, Swanson S D, Fowlkes J B and Emelianov S Y 1998 Shear Wave Elasticity Imaging: a New Ultrasonics Technology of Medical Diagnostics Ultrasound Med Biol 24 1419-35

Sarvazyan A P, Urban M W and Greenleaf J F 2013 Acoustic Waves in Medical Imaging and Diagnostics Ultrasound in Medicine \& Biology 39 1133-46

Sigrist R M S, Liau J, Kaffas A E, Chammas M C and Willmann J K 2017 Ultrasound Elastography: Review of Techniques and Clinical Applications Theranostics 7 1303-29

Song P, Bi X, Mellema D C, Manduca A, Urban M W, Greenleaf J F and Chen S 2016 Quantitative Assessment of Left Ventricular Diastolic Stiffness Using Cardiac Shear Wave Elastography: A Pilot Study J Ultrasound Med 35 1419-27

Song P, Urban M W, Chen S, Manduca A, Zhao H, Nenadic I, Pislaru S V, Pislaru C and Greenleaf J F IEEE International Ultrasonics Symposium,2014), vol. Series): IEEE) pp 109-12

Song P, Zhao H, Urban M W, Manduca A, Pislaru S V, Kinnick R R, Pislaru C and Chen S 2013 Improved shear wave motion detection using pulse-inversion harmonic imaging with phased array transducer IEEE Trans Med Imaging 32 2299-310

Strachinaru M, Bosch J G, van Dalen B M, van Gils L, van der Steen A F W, de Jong N, Geleijnse M L and Vos H J 2017 Cardiac Shear Wave Elastography Using a Clinical Ultrasound System Ultrasound Med Biol 43 1596-606 
Strachinaru M, Bosch J G, van Gils L, van Dalen B M, Schinkel A F L, van der Steen A F W, de Jong N, Michels M, Vos H J and Geleijnse M L 2019a Naturally Occurring Shear Waves in Healthy Volunteers and Hypertrophic Cardiomyopathy Patients Ultrasound Med Biol 45 1977-86

Strachinaru M, Geleijnse M L, de Jong N, van den Bosch A, Michels M, Schinkel A F L, van der Steen A F W, Bosch J G and Vos H J 2019b Myocardial Stretch Post-atrial Contraction in Healthy Volunteers and Hypertrophic Cardiomyopathy Patients Ultrasound Med Biol 45 1987-98

Sugimoto K, Moriyasu F, Oshiro H, Takeuchi H, Yoshimasu Y, Kasai Y and Itoi T 2020 Clinical utilization of shear wave dispersion imaging in diffuse liver disease Ultrasonography 39/3-10

Trutna C A, Rouze N C, Palmeri M L and Nightingale K R 2020 Measurement of Viscoelastic Material Model Parameters Using Fractional Derivative Group Shear Wave Speeds in Simulation and Phantom Data IEEE Trans Ultrason Ferroelectr Freq Control 67 286-95

Tzschatzsch H, Elgeti T, Rettig K, Kargel C, Klaua R, Schultz M, Braun J and Sack I 2012 In Vivo time harmonic elastography of the human heart Ultrasound Med Biol 38 214-22

Urban M W, Pislaru C, Nenadic I Z, Kinnick R R and Greenleaf J F 2013 Measurement of viscoelastic properties of in vivo swine myocardium using lamb wave dispersion ultrasound vibrometry (LDUV) IEEE Trans Med Imaging 32 247-61

Vejdani-Jahromi M, Freedman J, Kim Y-J, Trahey G E and Wolf PD 2018 Assessment of Diastolic Function Using Ultrasound Elastography Ultrasound Med Biol 44 551-61

Vejdani-Jahromi M, Freedman J, Nagle M, Kim Y-J, Trahey G E and Wolf P D 2017 Quantifying Myocardial Contractility Changes Using Ultrasound-Based Shear Wave Elastography J Am Soc Echocardiogr 30 90-6

Vejdani-Jahromi M, Nagle M, Jiang Y, Trahey G and Wolf P 2016 A comparison of acoustic radiation force derived indices of cardiac function in the Langendorff perfused rabbit heart IEEE Trans Ultrason Ferroelectr Freq Control 63 1288-95

Vejdani-Jahromi M, Nagle M, Trahey GE and Wolf P D 2015 Ultrasound shear wave elasticity imaging quantifies coronary perfusion pressure effect on cardiac compliance IEEE Trans Med Imaging $\mathbf{3 4}$ 465-73

Villemain O, Baranger J, Friedberg M K, Papadacci C, Dizeux A, Messas E, Tanter M, Pernot M and Mertens L 2020 Ultrafast Ultrasound Imaging in Pediatric and Adult Cardiology: Techniques, Applications, and Perspectives JACC Cardiovasc Imaging 13 1771-91

Villemain O, Correia M, Mousseaux E, Baranger J, Zarka S, Podetti I, Soulat G, Damy T, Hagège A and Tanter M 2018 Myocardial Stiffness Evaluation Using Noninvasive Shear Wave Imaging in Healthy and Hypertrophic Cardiomyopathic Adults JACC: Cardiovascular Imaging 12 1135-45

Voigt J U, Pedrizzetti G, Lysyansky P, Marwick T H, Houle H, Baumann R, Pedri S, Ito Y, Abe Y, Metz S, Song J H, Hamilton J, Sengupta P P, Kolias T J, d'Hooge J, Aurigemma G P, Thomas J D and Badano L P 2015 Definitions for a common standard for 2D speckle tracking echocardiography: consensus document of the EACVI/ASE/Industry Task Force to standardize deformation imaging Eur Heart J Cardiovasc Imaging 16 1-11

Vos H J, van Dalen B M, Heinonen I, Bosch J G, Sorop O, Duncker D J, van der Steen A F and de Jong N 2017 Cardiac Shear Wave Velocity Detection in the Porcine Heart Ultrasound Med Biol 43 753-64

Wang M, Byram B, Palmeri M, Rouze N and Nightingale K 2013 Imaging transverse isotropic properties of muscle by monitoring acoustic radiation force induced shear waves using a 2-D matrix ultrasound array IEEE Trans Med Imaging 32 1671-84 